Article

\title{
Analyses of Recent Sediment Surface Dynamic of a Namibian Kalahari Salt Pan Based on Multitemporal Landsat and Hyperspectral Hyperion Data
}

\author{
Robert Milewski *, Sabine Chabrillat and Robert Behling \\ GFZ German Research Centre for Geosciences, Telegrafenberg, D-14473 Potsdam, Germany; \\ chabri@gfz-potsdam.de (S.C.); behling@gfz-potsdam.de (R.B.) \\ * Correspondence: milewski@gfz-potsdam.de; Tel.: +49-331-288-1187 \\ Academic Editors: Magaly Koch, Richard Gloaguen and Prasad S. Thenkabail \\ Received: 27 July 2016; Accepted: 15 February 2017; Published: 18 February 2017
}

\begin{abstract}
This study combines spaceborne multitemporal and hyperspectral data to analyze the spatial distribution of surface evaporite minerals and changes in a semi-arid depositional environment associated with episodic flooding events, the Omongwa salt pan (Kalahari, Namibia). The dynamic of the surface crust is evaluated by a change-detection approach using the Iterative-reweighted Multivariate Alteration Detection (IR-MAD) based on the Landsat archive imagery from 1984 to 2015. The results show that the salt pan is a highly dynamic and heterogeneous landform. A change gradient is observed from very stable pan border to a highly dynamic central pan. On the basis of hyperspectral EO-1 Hyperion images, the current distribution of surface evaporite minerals is characterized using Spectral Mixture Analysis (SMA). Assessment of field and image endmembers revealed that the pan surface can be categorized into three major crust types based on diagnostic absorption features and mineralogical ground truth data. The mineralogical crust types are related to different zones of surface change as well as pan morphology that influences brine flow during the pan inundation and desiccation cycles. These combined information are used to spatially map depositional environments where the more dynamic halite crust concentrates in lower areas although stable gypsum and calcite/sepiolite crusts appear in higher elevated areas.
\end{abstract}

Keywords: salt pan; playa; hyperspectral; multitemporal; change detection; evaporite minerals

\section{Introduction}

Natural salt pan environments, also known as salt flats or playas, are some of the most geomorphological dynamic environments on Earth [1,2]. According to [3], there are approximately 50,000 salt pans on Earth. Although the area of individual salt pans is small, mostly less than a few square kilometers, except for prominent examples such as Salar de Uyuni (Bolivia) or Etosha pan (Namibia), the study of salt pan is important because of increasing population, agricultural demand and the hydrology of these dry regions becoming greatly stressed [4]. Salt pans are also one of the biggest sources of mineral dust emission in arid regions [5,6] especially in the southern Africa Kalahari desert (Botswana, Namibia, and Republic of South Africa) [7] and the specific salt pan mineralogy influences the susceptibility for dust emission [8-10]. For continued advances in understanding dust sources a spatially and temporally detailed assessment of their surface sediments is necessary [11]. Salt pans are also a potential significant carbon stock in the Kalahari environment [12] and the dynamic of salt pan surfaces is of great importance for the understanding of the carbon cycle and carbon fluxes of a pan systems. Furthermore, the sensitive interrelation between regional changes in climate patterns and tectonic activity within continents is often record in the pan sedimentary deposit, and insights on current surface processes are needed for a proper interpretation of paleoenvironmental conditions [13]. 
The harsh nature [14] and limited accessibility of salt pan environments makes them hard to study by conventional field mapping. This problem is exacerbated by ephemeral nature of salt pan evaporite minerals that is caused by sedimentological processes occurring at the surface as well as changes of the brine composition and the associated sequence of minerals one can expect to form in episodic dry-wet-dry cycles. The saline pan cycle, described by, e.g., Lowenstein and Hardie [15], provides a conceptual model of pan process dynamic and its effect on the pan deposits and associated evaporite mineralogy. In this model, the stages of salt pan cycles are described beginning at the desiccation stage (dry saline pan), followed by the flooding stage (brackish pan), than by the evaporative concentration stage (saline pan) and finally the return to the first status, the desiccation stage (dry saline pan). The ephemeral nature of salt pan evaporite minerals also emphasizes the need for multitemporal observations $[2,14]$. Over the last decades a limited number of studies have applied remote sensing techniques to study salt pan evaporite minerals and were able to provide spatial information on pan surfaces in terms of evaporite mineral discrimination supported by field observations. Most of them rely on traditional optical multi-spectral satellite sensors [1,13,16-19] that often do not provide the necessary spectral resolution to cover the spectral complexity of evaporite mineral assemblages on salt pan surfaces [20] and only provide a mono-temporal assessment. In comparison, analysis based on advanced hyperspectral imagery, also named imaging spectroscopy, are more sensitive for the identification and quantification of a wider range of evaporite minerals [13,21], and usually achieve higher modeling results [20]. EO-1 Hyperion is the first hyperspectral satellite that operates across the full solar-reflective spectrum with nominal spectral coverage form $0.4-2.5 \mu \mathrm{m}$ and $10 \mu \mathrm{nm}$ spectral response functions [22]. Although the applications of Hyperion imagery is limited by the sensor's relatively low signal-to-noise ratio $[16,23]$, spectral mapping results with Hyperion data compare reasonably well with results obtained from airborne hyperspectral sensors, including Hyperspectral Mapper (HyMap) [24] and Airborne Visible/Infrared Imaging Spectrometer (AVIRIS) [25,26]. Nevertheless, the availability of hyperspectral data, spaceborne or airborne, is very limited, which prevents time-series analyses of salt pan surfaces.

In this context, this paper is looking at the potential of modern remote sensing analyses for the study of the surface processes and dynamics of salt pans. This study combines both the potential of hyperspectral EO-1 Hyperion satellite data for the identification and mapping of major salt crust types and the potential of freely available 30 years Landsat time-series archives evaluating the temporal stability of the pan surface, linked with accurate elevation information from LIDAR data. The Omongwa salt pan in Namibian Kalahari, one of the largest and most studied salt pan in its region, is known for episodic flooding events and ongoing formation of evaporates minerals at the surface $[27,28]$. The Omongwa salt pan is taken as the object of investigation in this paper, as representing other extended saline pan bodies in arid regions of the world that could be similarly studied with newly available remote sensing data. The pan's spatial extend allows it to be complete covered by current spaceborne hyperspectral datasets (Hyperion) and therefore presents a suitable opportunity to test the potential of such datasets on a regionally important site with coherent coverage. The focus of the paper is placed on the development of the relationships between evaporite mineral mapping, time-series based surface dynamic and pan morphology to differentiate depositional environment of the investigated salt pan. State-of-the-art methodological tools in optical remote sensing for change detection analyses based on multitemporal Landsat data and for surface spectral mapping based on hyperspectral imagery are used in order to deepen our knowledge and understanding of the surface processes in the Omongwa pan.

\section{Study Area}

The Omongwa pan is located in eastern Namibia near Aminuis, $260 \mathrm{~km}$ southeast of Windhoek (Figure 1). With a size of $\sim 20 \mathrm{~km}^{2}$, it is the largest one in a series of pans that appear to be aligned along a former branch of the Nossob River system, with a southward palaeodrainage direction $[27,29,30]$. 
The climate in the Aminuis region is hot and semi-arid. It classifies as BWh according to the Köppen scheme [31] with average annual temperature and yearly precipitation of $19.8^{\circ} \mathrm{C}$ and $200-250 \mathrm{~mm}$ respectively. The rainfall is highly seasonal with $90 \%$ of the total precipitation occurring in the wet season from December to April. The interannual precipitation variation is very high, resulting in occasional draught years with down to $\sim 40 \%$ of the average amount [32]. The salt is very flat with a mean elevation of $\sim 1200 \mathrm{~m}$ above sea level. The surrounding Kalahari landscape is characterized by an undulating linear dune system typically in a NW-SE direction (as shaped by the prevailing winds) with elevation magnitudes of $\sim 1-3 \mathrm{~m}$ between dune crest and interdune valley. South of the pan, a lunette dune rises up to $\sim 50 \mathrm{~m}$ above the pan floor level.

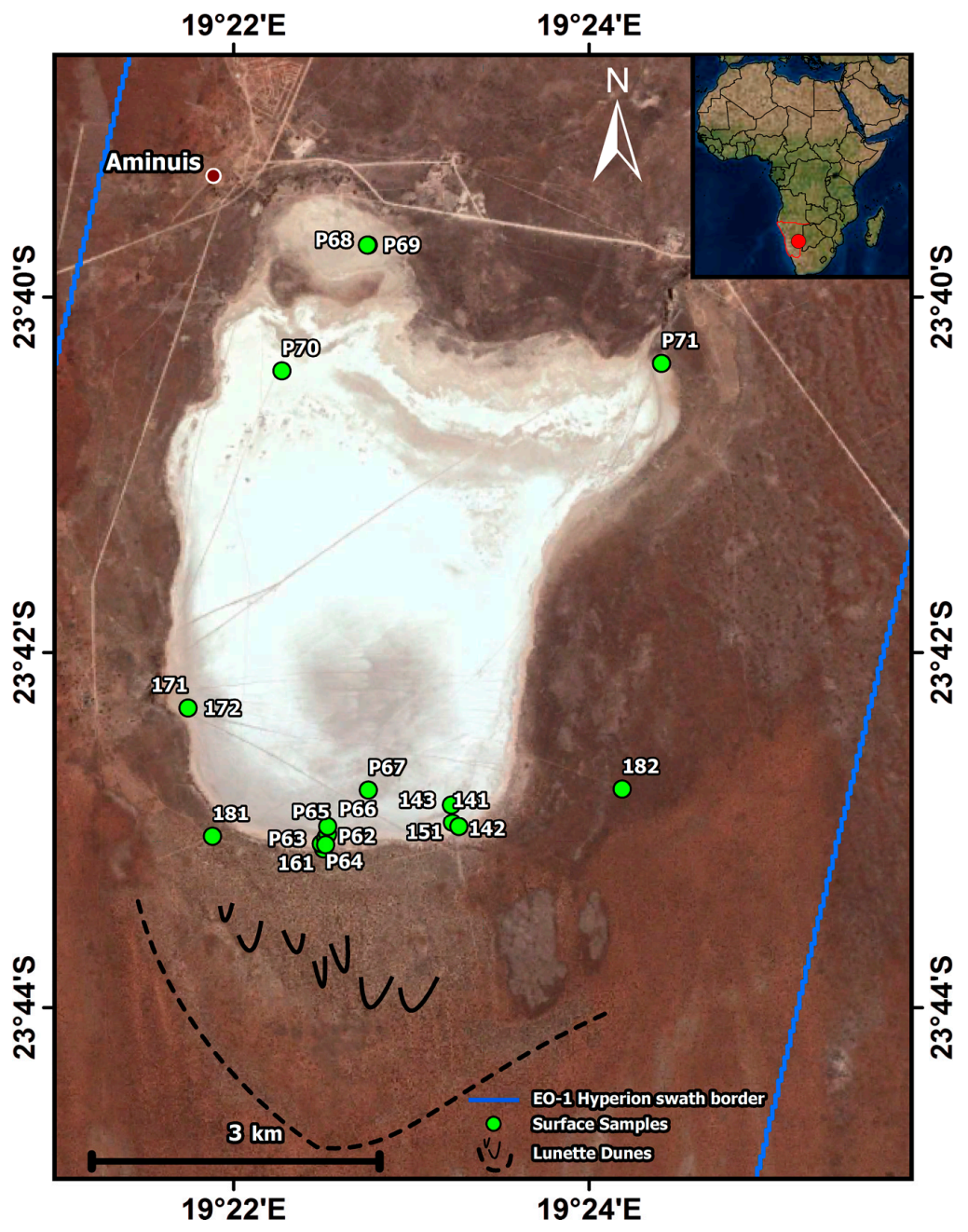

Figure 1. Location and overview of the Omongwa salt pan showing surface sample location, position of lunette dunes and extent of EO-1 Hyperion image (Basemap source: DigitalGlobe RGB image, September 2013, provided by Google Inc. (Mountain View, CA, USA)).

The pan evolved in calcareous deposits of Kalahari Group which are exposed in the paleo river valley and in interdune space of shallow dunes [27,33,34]. Along these paleo river courses, Early Kalahari deposits were cemented by pedogenic and groundwater calcretes driven by re-occurring changes in moisture and sedimentary regime during the Tertiary until the Late Pleistocene [35]. Prominent outcrops of calcareous material appear along the pan margins [36], e.g., $~ 1 \mathrm{~m}$ high scarp at the northeastern margin of Omongwa pan. Detailed mineralogical information of the pan deposits are known from a diagonal sampling survey from the SW to NE of Omongwa pan conducted by Mees [27] in 1991 and 1992. The upper lithological unit (top $~ 50 \mathrm{~cm}$ ) of the pan deposits is mainly 
sand-sized detrital grains with varying contents in halite (>30\%), gypsum $(5 \%-40 \%)$ and calcite $(10 \%-20 \%)$ mixed with the clay and mica minerals sepiolite, muscovite, and smectite. The lower units have evaporite-filled cracks in the upper part (vadose zone) and generally increase in calcite content with depth until the calcareous mudstone bedrock is met in up to $3.5 \mathrm{~m}$ below the surface [27]. It is further noted that the mineralogy of the pan is sensitive to changes of the hydrological conditions. The point based mineralogical description together with the analysis of the general pan environment is very helpful for the evaluation of the remote sensing based mapping of the surface mineralogy as it provides a baseline for the interpretation of this study. In general, the Kalahari Group is relatively thin in this region with a thickness of $<10 \mathrm{~m}$ [37], which has been recognized from the cuttings of several water boreholes in the Aminuis region [35,38]. One borehole (WW26165) directly north of the Omongwa pan revealed only $1 \mathrm{~m}$ of Kalahari Group deposits [38]. They overlie more than $50 \mathrm{~m}$ of Pre-Kalahari basalts of the Kalkrand Formation. The surroundings landscape of the pans are generally covered by the reddish sands of the Kalahari Group [30,35], which are classified as Rubi-Feralic Arenosols, ARo (red, iron rich, sandy soils) according to the WRB system [39], whereas the calcareous deposits along the paleo riverbed form greyish soils that classify as Petric Calcisols, CLp (soils with secondary lime accumulation and strongly cemented layers) [34].

The pan lacks significant surface inflow, as surface runoff is minimized by the high infiltration rates of the Kalahari sands and topographically limited to by distance of the next dune crest. The hydrogeological situation of the study region is very complex due to the occurrence of several pre-Kalahari normal faults as well as rapid facies changes in the Kalahari Group deposits [35,40]. Borehole data near Aminuis suggest that the groundwater level is reached below the Kalahari Group deposits between 13 and $43 \mathrm{~m}$ in the Pre-Kalahari basalt layers [38]. However the calcareous mudstone of the Omongwa pan is likely to support a locally perched groundwater tables above the regional aquifer due to its low permeability. This is supported by the observations of fluctuating groundwater levels of 25-150 cm between the wet and the dry season of 1991-1992 [27] as well as temporally formation of shallow open waterholes fed by groundwater discharge [30].

\section{Materials and Methods}

\subsection{Field and Laboratory Analysis}

Two field campaigns for surface characterization and sampling took place in October 2014 and June 2015, which represent the end and beginning of the dry season respectively. Prior to both visits small precipitation events of $<5 \mathrm{~mm}$ led to slight moist conditions in the central part of the Omongwa pan [41], which limited the accessibility to the most outer $\sim 500 \mathrm{~m}$ of the pan, and lead to a sample size of 17 surface samples.

Fieldwork consisted of acquisition of surface samples and field reflectance spectroscopy measurements along transects into the pan and for sites of interest representative for the variability of surface conditions and presumed sediment mixtures of the pan (see Figure 1). Sampling was performed in homogeneous areas collecting the top surface crust $(<2 \mathrm{~cm})$. These samples were composed of 5 to 10 sub-samples collected at random locations within a $5 \mathrm{~m}$ wide square around the center point for each site of interest. Prior to sampling, field spectra of the untouched surfaces were collected at the selected locations using an FieldSpec 3 point spectroradiometer (ASD Inc., Boulder, CO, USA), covering the VNIR-SWIR spectral range [42]. Per site of interest, 5 spectra were acquired at nadir configuration from $1 \mathrm{~m}$ height with a $\sim 25 \mathrm{~cm}$ target radius from the center of each location. The measurements were calibrated to a barium-sulfate white reference standard to determine relative reflectance, and were subsequently corrected for detector offset and averaged for higher signal-to-noise ratio. All spectra and center of sampling location were geolocated using the Global Positioning System (GPS).

Geochemical and VNIR-SWIR spectral analyses of surface samples were conducted in the laboratory including the parameters mineralogy, grain size, $\mathrm{pH}$, and conductivity. Initial sample preparation comprised of sub-sampling and drying at $105^{\circ} \mathrm{C}$. After the removal of organic material 
and carbonates using $10 \% \mathrm{H}_{2} \mathrm{O}_{2}$ and $17 \% \mathrm{HCl}$, respectively, sample texture was determined by a combination of wet-sieving (particles $>63 \mu \mathrm{m}$ ) and sedimentation (particles $<63 \mu \mathrm{m}$ ) following [43]. Electrical conductivity was measured in a 1:5 ratio with bi-distilled water after [44] and $\mathrm{pH}$ in a $0.01 \mathrm{M}$ $\mathrm{CaCl}_{2}$ suspension after [43]. The sub-samples used for powder X-ray diffraction (XRD) were crushed in a vibrating disc mill to a particle size $<63 \mu \mathrm{m}$. Powder samples were measured using $\mathrm{Cu}-\mathrm{K} \alpha$ radiation. Diffractograms were recorded from $5^{\circ}$ to $85^{\circ} 2 \theta$ using a PANalytical Empyrean diffractometer (PANalytical GmbH, Kassel, Hesse, Germany). Results were analyzed using the software Bruker EVA (Bruker Corporation, Billerica, MA, USA) for mineral identification and AUTOQUAN (Agfa NDT Pantak Seifert GmbH \& Co. KG, Ahrensburg, Schleswig-Holstein, Germany) for quantification. Laboratory spectral characterisation was performed with the ASD FieldSpec 3 point spectroradiometer under controlled light illumination simulating spaceborne observations (sensor nadir viewing, light source azimuth $35^{\circ}$ ). Finally, two spectral libraries of Omongwa sediment surfaces were created associated with field and laboratory optical signatures.

\subsection{Remote Sensing Change Detection Analyses}

The multitemporal analysis uses all available, cloud free Landsat images of the study area at World Reference System-2 path/row 176/76 acquired through the USGS EarthExplorer data portal [45]. The time series covers the last 3 decades (1984-2015) and is composed of imagery from three different satellite and sensor generations of the Landsat Mission. From a total of 146 cloud-free scenes, the majority (98) originate from Landsat 5 (TM), 16 from Landsat 7 (ETM+) and 32 from Landsat 8 (OLI). The three sensors have the same spatial resolution of $30 \mathrm{~m}$, but slightly different spectral coverage or even additional bands [46]. Only the six reflective bands (Blue, Green, Red, NIR, MIR, and SWIR) common to all sensors are used. On average, the data series is composed of five images per year, but the distribution is highly irregular. Data gaps occur during the mid-1980s and from late 2011 to early 2013 when Landsat 5 data were discontinued and Landsat 8 was not yet operative. Between 2003 and 2013, data availability further decreased to 1-4 scenes/year after the failure of the Scan Line Corrector (SLC) of the Landsat 7 ETM+ sensor, which makes the data unusable for change-detection approaches such as in this study.

The Landsat data were pre-processed to top of atmosphere (TOA) reflectance by the Landsat Ecosystem Disturbance Adaptive Processing System (LEDAPS) [47] including the conversion of calibrated Digital Numbers (DNs) to absolute units of at-sensor spectral radiance and reduction of in scene-to-scene variability due to different solar/sensor geometry and Sun/Earth distance. Top of atmosphere (TOA) reflectance is used to normalize scene radiances differences due to variations in solar illumination, sensor viewing geometry, and seasonality (Earth-Sun distance). Surface reflectance products for all optical bands are also available [48,49]. However the atmospheric correction applied by LEDAP follows the popular dense vegetation (DDV) approach [50], which is known to provide limited accuracy in arid environments [51], as it depends on finding sufficient and evenly distributed dark objects such as dense vegetation or water bodies that are completely absent in the study area. Because of the lack of such surfaces in the study area, it is unclear on which basis the estimation of the aerosol properties is performed and it is likely that an artificial bias is introduced to the data instead of a correction. Furthermore the provisional AOT estimation for the Landsat 8 OLI images is based on coarse $\left(0.05^{\circ}\right)$ MODIS data [52], which can lead to tilling artifacts in the processed image [49] that were also identified on images of the Omongwa pan. Due to the current limitations in corrections to surface reflectance especially applied in arid areas, TOA reflectance is used in this paper for the change detection analyses. An adapted procedure for change detection analysis is used that limits the atmospheric influence.

In a first step, to restrict the change detection analyses to the dynamic of the pan surface deposits in dry state, Landsat images related to pan flooded state have to be excluded from the dataset. For this purpose, $\mathrm{Xu}$ 's Normalized Differenced Water Index (NDWI) [53], a band ratio using the green and mid-infrared (MIR) band, is derived from the Landsat record. This adaption of the NDWI is sensitive 
even to shallow water bodies [54]. A conservative threshold of 0.5 was selected to filter scenes featuring surface water. This restriction robustly excludes images that show an inundated pan surface, as well as scenes which have significant moisture in the top layer of pan deposits. Exactly how the selected NDWI threshold relates to the water content of the surface sediments is scene dependent and cannot be profoundly estimated from the remote sensing image. A total of 30 scenes were water covered or in very wet surface conditions and discarded for further analyses.

On the remaining 116 Landsat images a change detection analysis is applied. The described discontinuities and gaps of the Landsat record restrict popular approaches of time series analyses based on temporal trajectories such as the Breaks For Additive Season and Trend (BFAST) [55] and Reversed Ordered Cusum (ROC) [56] procedures. Discontinuous datasets do not meet the need of many curve-fitting time series methods to establish a "stable" reference model from historical data [57], e.g., 16-day time series over 2 years [58]. Accordingly, a temporally more robust approach of bi-temporal change detection, the Iterative-reweighted Multivariate Alteration Detection (IR-MAD) developed by A.A. Nielsen [59] is selected. The IR-MAD has been successfully used for different applications and sensors, e.g., to detect changes caused by floods from coarse AVHRR imagery [60], mining activity [61,62] and forest disturbance from Landsat data [63], as well as earthquakes from high resolution imagery of GF-1/PMS and GeoEye-1 [64,65]. The core idea of MAD is to find maximum differences between two images by removing correlations between them as much as possible [66]. The MAD algorithm transforms two sets of multivariate observations (in this case two multispectral satellite images covering the same geographical area acquired at different points in time) into a difference between two linear combinations of the original variables explaining maximal change (i.e., the difference explaining maximal variance) in all variables (wavelength) simultaneously [67]. IR-MAD is an improvement of the MAD approach. In order to increase the detection of observations, whose status over time is uncertain, weights are put on difficult observations that exhibit small change according to their change probability in the previous run. In each iteration a better no-change background is identified, achieving a better separability between the change and no-change classes [59].

The IR-MAD can be classified as a bi-temporal linear data transformation type of change detection [68]. This change-detection approach is most suitable to observe the type of changes that can be expected in the salt pan environment, due to the following properties: (1) It can detect modifications (changes in crust composition) and not only discrete conversions (crust type A to crust type B); (2) it is sensible to progressive as well as abrupt changes (slow deflation of particles, loss and build-up of new crust after inundation); (3) it can work with the temporal sampling rates of the observations (irregular, data gaps) [68]. A further advantage over most other change detection methods is that IR-MAD is invariant to linear transformations of the original image intensities [59,69]. The method is robust to differences in atmospheric conditions or sensor calibrations at two acquisition times, which greatly reduces the requirements on radiometric correction or normalization [66]. This is an important advantage for this study because it limits the atmospheric influence on the change detection result when using TOA reflectance data. A general constraint to bi-temporal change detection methods such as the IR-MAD is the loss of data due to a number of contaminations or errors such as SLC-off data gaps [57] and cloud cover [70]. Although well-performing correction approaches have been proposed for data gaps with information derived from neighboring pixels [71] or even other sensors [72], interpolation or the inclusion of extraneous data can introduce additional errors [73,74]. For this, SLC-off acquisitions as well as clouded scenes are discarded.

In this study, the python implementation of IR-MAD by [75] is used to which some modifications were made that allow for batch processing of the Landsat image stack. For the Omongwa pan subset a total of 115 bi-temporal change maps are produced. The IR-MAD processing always converged to a no-change background before hitting the defined maximum of 50 iterations. Besides providing the basis for the no-change probability calculation, the sum of squared, standardized MAD variates, also called $\chi^{2}$ image [76] is used as a general measure of change of the pan surface similar to [65,77,78]. From each bi-temporal IR-MAD analysis of the Landsat dataset, the final $\chi^{2}$ image is used to derive 
aggregated change over the time-series to differentiate dynamic pan areas from radiometrically more stable regions.

\subsection{Remote Sensing Surface Characterisation}

\subsubsection{EO-1 Hyperion Mineralogical Mapping}

One EO-1 Hyperion hyperspectral image is used in this study. It has been acquired on 7 September 2014 at 07:34 UTC with a sun azimuth of $63^{\circ}$ and a sun elevation of $36^{\circ}$. The Hyperion sensor covers the VNIR and SWIR spectral region (400-2500 nm) with 198 calibrated bands of $\sim 10 \mathrm{~nm}$ width at a spatial resolution of $30 \mathrm{~m}$ [79] similar to the Landsat imagery. The spatial extent is $7.5 \mathrm{~km}$ wide $105 \mathrm{~km}$ long. The signal-to-noise ratio (SNR) is specified as 140:1 to 190:1 for the VNIR and 96:1-38:1 for the SWIR detector [79].

An automated pre-processing chain for EO-1 Hyperion data developed by [80] is used that provides georeferenced surface reflectance data. The L1 radiance data (L1R), L1T radiance terrain corrected data, acquisition parameters from the metadata and an ASTER $30 \mathrm{~m}$ DEM, freely distributed through the USGS EarthExplorer data portal [45] are used. Data processing includes rescaling to radiance, removal of the spectrally overlapping bands, bad band detection, reductions for dead pixel and erroneous detector columns, as well as corrections for intra-band spatial shifts, keystone, erroneous co-registration, radiometric miscalibration. Part of the processing chain is the atmospheric correction as proposed in [81,82] originally designed for the EnMAP Box [83]. It includes a complex Radiative Transfer Modeling (RTM), Aerosol Optical Thickness (AOT), Columnar Water Vapor (CWV) retrieval as well as spectral Smile and adjacency correction [80]. Georeferencing is performed via GCP (Ground Control Point) selection and first-order transformation using ENVI 5.3 [84] between the corrected image and the orthorectified L1T Hyperion image. The geometrical transformation is applied at the end on the results to prevent resampling effects on the spectral analyses. The pre-processing chain was used previously for geological applications, e.g., by Mielke et al. [85,86] proving that it can deal with the sensor limited quality and still delivers reflectance data that are adequate for mineralogical identification analyses.

Spectral mixture analyses (SMA) [87,88] implemented in ENVI 5.3 [84] is used to determine the mineralogy of the pan surface based on the EO-1 Hyperion image. SMA is a physically-based model that transforms radiance or reflectance values to physical variables that are linked to the subpixel abundances of surface components within each pixel $[89,90]$. SMA proved useful specifically for the mapping of salt and gypsum surfaces [13,91], but also in a wide range of other applications, such as vegetation (e.g., [92]), mineralogical and lithological mapping (e.g., [93,94]), and soil degradation assessment [95]. The SMA analysis assumes a linear mixing of the scene constituents in the sensor field-of-view and is particularly adapted to arid landscapes with aerial mixing. In SMA, the reflectance of a pixel is determined by the sum of the reflectance of each material within a pixel multiplied by its fractional cover. Most crucial for the quality of an unmixing model is the selection of endmembers that account for the spectral variability of the data, while remaining physically meaningful $[89,96]$. Instead of focusing on specific absorption features, SMA uses the whole reflectance of the VNIR-SWIR selected endmember to map subpixel abundances. This is especially helpful in the study of salt affected surfaces that often do not show diagnostic absorption features outside of the known water (vapor) absorption region [97]. The inherent dimensionality of the EO-1 Hyperion data is examined via minimum noise fraction transformation [98] and image endmembers are extracted from the edges of the data cloud. Following [99], candidate endmembers extracted from the image are further redefined in minimum noise fraction transformed space to assign the purest and least noisy pixel spectra as final endmembers. In order to focus on the fractional cover of different mineralogical crust types and to reduce the spectral variability of the data set, the areas outside the Omongwa pan are excluded from the image for SMA analyses using an albedo threshold. 


\subsubsection{LiDAR Digital Surface Model}

Airborne Light Detection and Ranging (LiDAR) data were acquired with a Riegl LMS-Q780 at an altitude of $2850 \mathrm{~m}$ above ground level over the Omongwa pan on 6 June 2015 during a GFZ/DIMAP airborne campaign [100]. The pan surface was partly moist, but not flooded at the time of overflight. A total of nine flightlines were recorded with a swath width of $\sim 3 \mathrm{~km}$ and an overlap of approximately $60 \%$ and an average point density of $2.1 \mathrm{pts} / \mathrm{m}^{2}$. Fundamental accuracy assessed through calibration flights showed $\pm 10 \mathrm{~cm}$ vertical and $\pm 15 \mathrm{~cm}$ horizontal accuracy within a of $95 \%$ confidence level. For the topography of the Omongwa pan a $1 \mathrm{~m}$ grid Digital Surface Model (DSM) was generated from the first return LiDAR mass point data by converting the points to a Triangulated Irregular Network (TIN) surface mesh and the TIN to a regular raster grid with Natural Nearest Neighbor interpolation using the program Terrasolid TerraScan. Values are given in meters above sea level (a.s.l.)

\section{Results}

\subsection{Field and Laboratory Analysis}

Field observations showed highly heterogeneous pan environments that could be grouped into three different crust types (Figure $2 \mathrm{a}-\mathrm{c}$ ): (a) halite $(\mathrm{NaCl})$ is present over the whole pan surface in variable amounts, and is identifiable as bright white surfaces, with puffy structure and blisters; (b) the sulfate mineral gypsum $\left(\mathrm{CaSO}_{4} \cdot 2 \mathrm{H}_{2} \mathrm{O}\right)$ is a major constituted of the crust at the pan margin and appear as a smoother and darker surface; and (c) carbonate crust appears in the form of some sediment accumulation mixed with salt composition, linked with carbonate outcrops at the border of the pan (Figure 2e). Surface roughness as well as the general brightness are very variable between the crust types and are also effected by anthropogenic disturbances (Figure 2f). In general, the pan surface is bare of any vegetation with the exception of the most northern part that is sparsely covered with patchy bushes that increase in density in the direction of the pan margin (Figure 2d).
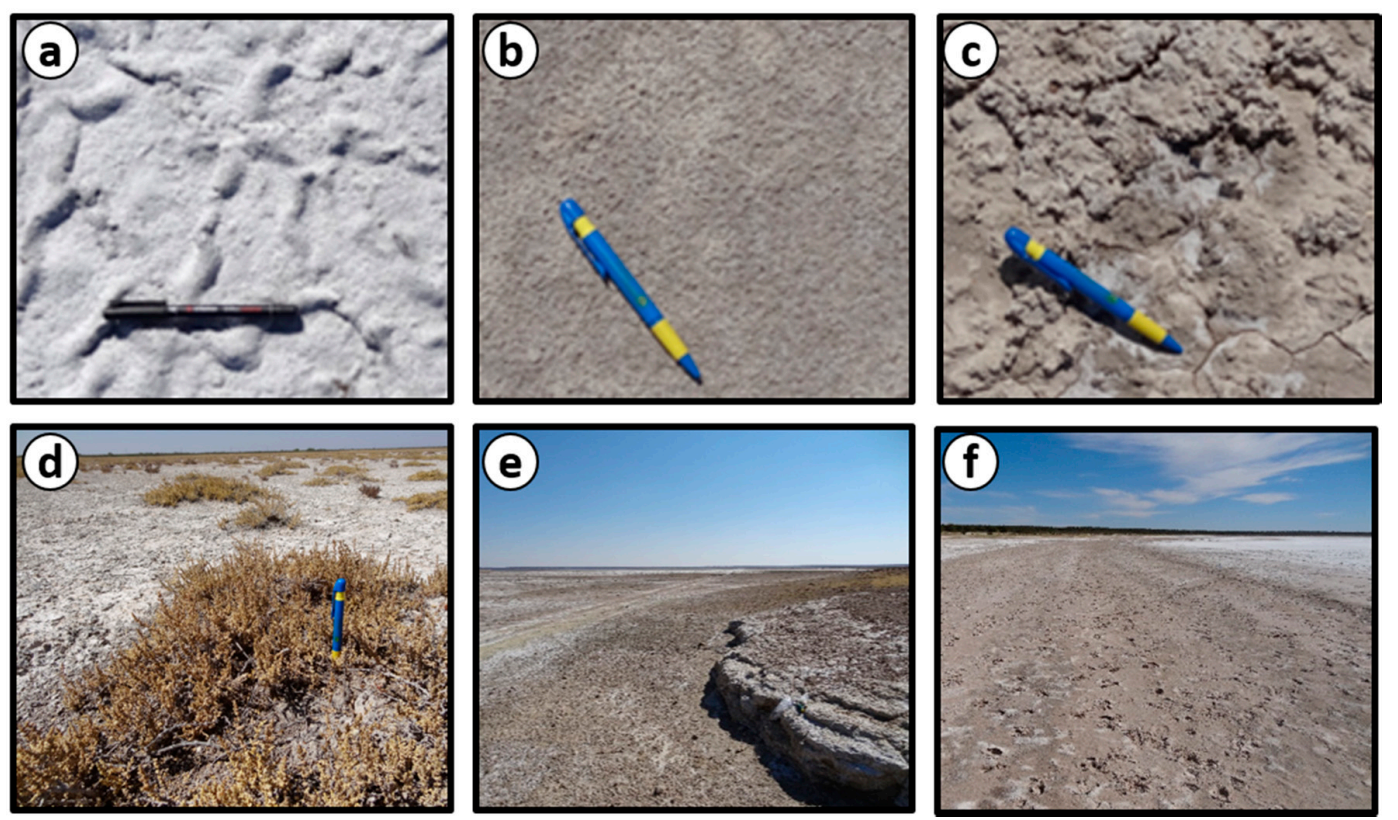

Figure 2. Different types of pan surfaces composed of detrital and evaporite mineral mixtures and environments of the Omongwa pan in October 2014 and June 2015: (a) bright efflorescent halite crust, puffy salt blisters; (b) smooth structure gypsum surface; (c) rough carbonate/sepiolite crust; (d) vegetated patches of the northeastern pan area; (e) $\sim 50 \mathrm{~cm}$ high outcrop of the carbonatic mudstone bedrock, northern pan margin; and (f) surface disturbed by cattle treading at the southern pan margin; length of pen used for scale $\sim 13 \mathrm{~cm}$. 
From field spectral measurements as well as laboratory geochemical analysis, the major mineralogical components in the salt pan sediments could be identified and related to the different crust types. Figure 3 shows the field spectra for the three representative crusts types and Table 1 the geochemical results of all samples. According to the XRD analysis, Omongwa halite field endmember (sample 141, Figure 2a) is almost pure halite $(\mathrm{NaCl})(94 \%)$ mixed with small amounts of gypsum $\left(\mathrm{CaSO}_{4} \cdot 2 \mathrm{H}_{2} \mathrm{O}\right)(3 \%)$. The associated field spectrum shows a constant high reflectance level in the VNIR with almost no slope, which is typical for pure halite [101] or halite rich salt pan sediments [24]. The absorption and general lower reflectance level of the Omongwa halite field spectrum compared to standard laboratory halite powder spectral reflectance from the USGS spectral library [102] originates from the partially moist conditions at the time of field spectral acquisition as well as from the intermixture with some gypsum at that location. Laboratory spectral measurements of this sample after air drying for several days result in reflectance level up to $70 \%$ in the VNIR, close to reference halite spectral characteristics. The field spectrum of the second crust type (sample P65, Figure $2 b$ ) is characterized by strong absorption features in the SWIR at $\sim 1750 \mathrm{~nm}$ and $\sim 2200 \mathrm{~nm}$ as well as the unique triplet absorption around $1500 \mathrm{~nm}$, which are characteristic for gypsum spectral properties $[101,103,104]$. The XRD analysis also confirms the high gypsum content $(83 \%)$ mixed with some halite. The third surface crust type (sample P68, Figure 2c) is dominated by high calcite $\left(\mathrm{CaCO}_{3}\right)$ content $(45 \%)$, mixed with the clay mineral sepiolite $\left(\mathrm{Mg}_{4} \mathrm{Si}_{6} \mathrm{O}_{15}(\mathrm{OH})_{2} \cdot 6 \mathrm{H}_{2} \mathrm{O}\right)(16 \%)$. The associated field spectrum shows a strong absorption feature at $\sim 2340 \mu \mathrm{m}$. Both calcite and sepiolite have their characteristic absorption features at this wavelength [101].

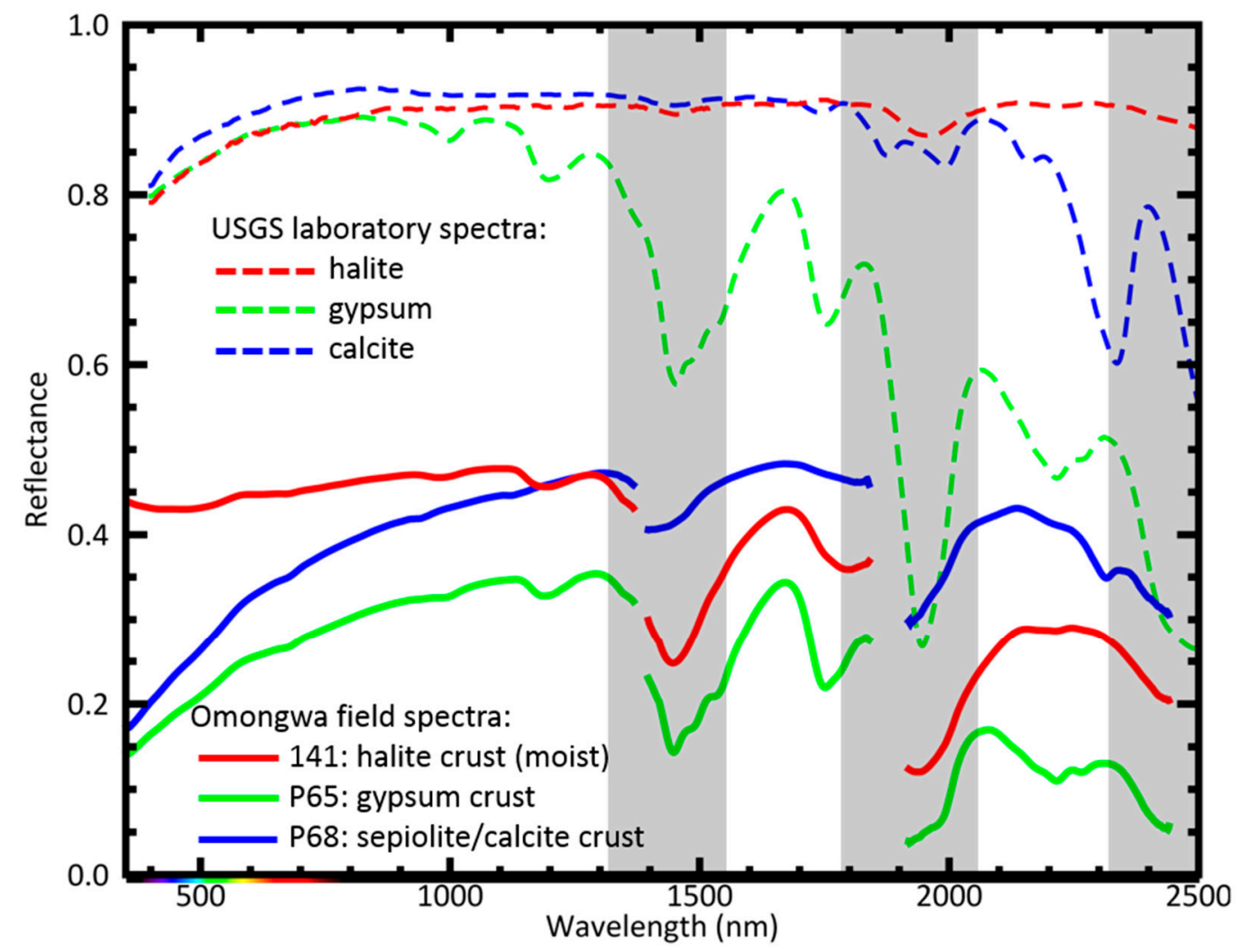

Figure 3. Field spectra (straight lines) of the three characteristic pan surface types of the Omongwa pan associated with halite crust (sample 141), gypsum crust (sample P65), and sepiolite/calcite crust (sample P68) and USGS laboratory spectra [102] (dotted lines) of the main minerals. The grey overlay indicates wavelength regions of atmospheric absorption and sensor lower signal-to-noise ratio not useable for Hyperion analyses. 
Table 1. Properties of Omongwa surface samples. Locations of field samples are mapped in Figures 1 and $7 \mathrm{~b}$.

\begin{tabular}{|c|c|c|c|c|c|c|c|c|c|c|c|}
\hline \multirow{2}{*}{ Label } & \multicolumn{6}{|c|}{ Mineralogy (bulk XRD) Semi-Quantitative Estimates (\%) } & \multirow{2}{*}{$\mathrm{pH}$} & \multirow{2}{*}{$\begin{array}{c}\text { EC } \\
(\mathrm{dS} / \mathrm{m})\end{array}$} & \multicolumn{3}{|c|}{ Grain Size (\%) } \\
\hline & Quartz & Halite & Gypsum & Calcite & Sepiolite & Dolomite & & & Clay & Silt & Sand \\
\hline P62 & 79 & - & 21 & - & - & - & 7.9 & 1.9 & 2 & 3 & 95 \\
\hline P63 & 19 & 5 & 75 & - & - & - & 8.6 & 17.6 & 1 & 4 & 95 \\
\hline P64 & 17 & 36 & 47 & - & - & - & - & - & - & - & - \\
\hline P65 & 3 & 14 & 83 & - & - & - & 8.5 & 42.3 & 5 & 4 & 91 \\
\hline P66 & 13 & 41 & 44 & - & 1 & - & - & - & - & - & - \\
\hline P67 & 3 & 46 & 45 & - & 5 & - & 8.4 & 80.7 & 4 & 40 & 56 \\
\hline P68 & 36 & 3 & - & 45 & 16 & - & 8.3 & 10.8 & 4 & 37 & 59 \\
\hline P69 & 28 & 15 & - & 41 & 15 & - & 8.7 & 36.5 & 8 & 39 & 53 \\
\hline P70 & 32 & 16 & 26 & 15 & 11 & - & 8.6 & 33.7 & 2 & 34 & 64 \\
\hline P71 & 26 & 7 & - & 47 & 6 & 14 & - & - & - & - & - \\
\hline 141 & 1 & 94 & 3 & - & - & - & - & - & - & - & - \\
\hline 142 & 63 & 9 & 15 & 7 & 5 & - & 8.8 & 23.4 & 7 & 24 & 69 \\
\hline 143 & 1 & 52 & 38 & 4 & 5 & - & 8.3 & 129.7 & 6 & 73 & 21 \\
\hline 151 & 64 & 21 & 7 & 9 & - & - & 9.1 & 48.2 & 2 & 17 & 81 \\
\hline 161 & 14 & 3 & 79 & 3 & - & - & 8.2 & 11.6 & 2 & 11 & 88 \\
\hline 171 & 27 & 50 & 17 & 4 & - & - & 9.0 & 98.0 & 4 & 24 & 72 \\
\hline 172 & 41 & 17 & 33 & 8 & - & 1 & 8.7 & 42.3 & 2 & 16 & 82 \\
\hline
\end{tabular}

\subsection{EO-1 Hyperion Analyses}

Four images endmembers are extracted from the Hyperion imagery and shown in Figure 4. Overall the main spectral properties of the first three extracted endmembers are similar to the field spectra of the different crust types. However some differences are observed due to variable sensor characteristics and surface conditions. The extracted Hyperion endmember spectrum (EM 1 in Figure 4) for halite crust has a high reflectance level around $70 \%$ and significant spectral slope in the shorter wavelength compared to the field halite spectrum. The higher general albedo can be attributed to the dry conditions of the central pan surface at the time of Hyperion image acquisition, whereas the differences in the shorter wavelength could result from a higher proportion of silicates exposed due to the larger Hyperion pixel or that are present in the central part of the pan not accessible during the field campaigns. In the image endmember that corresponds to the gypsum crust (EM 2 in Figure 4), the triplet absorption around $1500 \mathrm{~nm}$ visible in the gypsum field spectrum is within the water vapor atmospheric absorption bands and cannot be observed, but the other absorption features at $~ 1750$ and $\sim 2200 \mathrm{~nm}$ are well defined. The characteristic absorption feature of the calcite and sepiolite crust at $2340 \mathrm{~nm}$ exceeds the usable spectral range of the Hyperion scene. However the left slope and shoulder of the absorption feature can still be identified at $\sim 2300 \mathrm{~nm}$ in the image endmember (EM 3 in Figure 4). Because the observed absorption at $\sim 2300 \mathrm{~nm}$ can originate from both minerals, we refer this endmember as calcite/sepiolite. In the surface reference samples analyzed by XRD the minerals mostly occur together with $\sim 2-3 \times$ higher share of calcite. Besides the spectrally and mineralogically well-defined endmembers of halite, gypsum, and calcite/sepiolite, a fourth image endmember had to be added to account for the spectral variability within the scene. This endmember is associated with disturbed halite crust of lower reflectance (EM 4 in Figure 4). 


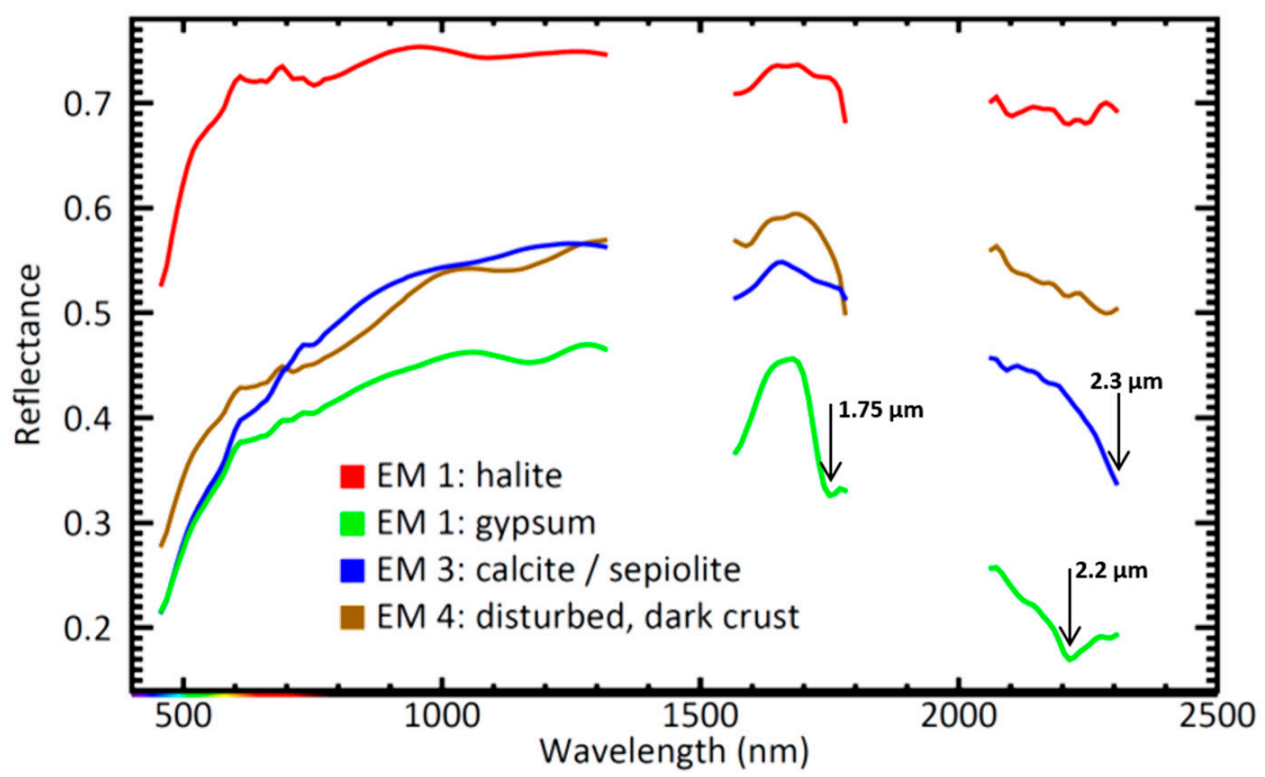

Figure 4. Hyperion endmember image spectra used for the spectral mixing analysis. Arrows indicate the position of diagnostic absorption features for gypsum and calcite/sepiolite crust.

Figure 5 show the SMA result of the identified pan crust components based on the Hyperion image. Each abundance map represents the fraction of the surface type on the Omongwa salt pan in: (a) bright halite crust; (b) gypsum crust; (c) calcite and sepiolite crust; and (d) disturbed, dark crust. In general, all endmembers have their abundances well mapped with no component exceeding 1 . The accuracy of the unmixing model is assessed through the root mean squared error (Figure 5e). The RMSE image shows that the overall pan surface is well explained with the linear mixture of the four selected endmembers except for higher RMSE areas at: (1) the northeast corner and western pan border associated with heavy cattle disturbances; (2) the mainly diagonal SW-NE lines crossing the pan, which are used as driving shortcuts across the pan during the dry season as well as cattle path ways; and (3) the parallel, vertical stripes $\left(\sim 11^{\circ}\right)$, associated with remaining sensor noise that were not removed through the pre-processing procedure. In general the performance of the unmixing model is very good with an overall mean RMSE of $~ 1 \%$ comparable to equivalent studies, e.g., [105] achieved an mean RMSE of $\sim 2 \%$ using linear unmixing on Hyperion data to map salt effect soils or [106] getting the same accuracy range for the abundances of vegetation, soil and limestone bedrock. The SMA mapping shows that more than half of the pan surface is dominated by halite crust in variable amounts (Figure 5a). The highest abundances are mapped in the central part and in a circular shape in the southern half of the pan, whereas the border region and the anthropogenic pathways have minimal fractions of halite crust. In most regions the distribution of gypsum crust appears to be inversely related to the halite crust. Highest gypsum composition is found at the southern pan border, in the south-central circular shape and in a $\sim 1.5 \mathrm{~km}$ long stripe in the northern pan area (Figure $5 \mathrm{~b}$ ). The occurrence of calcite and sepiolite crust is confined to the northern part of the pan and to the pan border (Figure 5c) close to outcrops of the carbonatic bedrock that were observed in the field (Figure 2e). The disturbed, dark crust endmember (Figure 5d) is mainly associated with the cattle and human disturbance of the salt crust through the pathways crossing the pan and at the border regions (e.g., Figure 2f). In these areas the top crust is at partly removed and the subsurface material is exposed. The subsurface is usually less concentrated in evaporite minerals and more mixed with the clastic, quartz-rich material of the pan. This is reflected by the geochemical analyses of subsurface field samples 142 (halite: 9\%, quartz: 63\%) and 172 (halite: $17 \%$, quartz: $41 \%$ ), directly sampled under the surface crust of samples 141 (halite: $94 \%$, quartz: $1 \%$ ) and 171 (halite: $50 \%$, quartz: $27 \%$ ), respectively at a depth at a depth of $\sim 10 \mathrm{~cm}$. The sub-surface samples show decreased halite and increased quartz content compared to surface 
samples (Table 1). In addition to mineralogical differences, the physical properties of the salt pan surface are altered by cattle trampling, increasing the surface roughness [107], which may also cause the reflectance to decrease even at similar salt content by casting micro shadows [108]. The rougher surface crust is also likely to be more moist [109] adding to the decrease in reflectance.
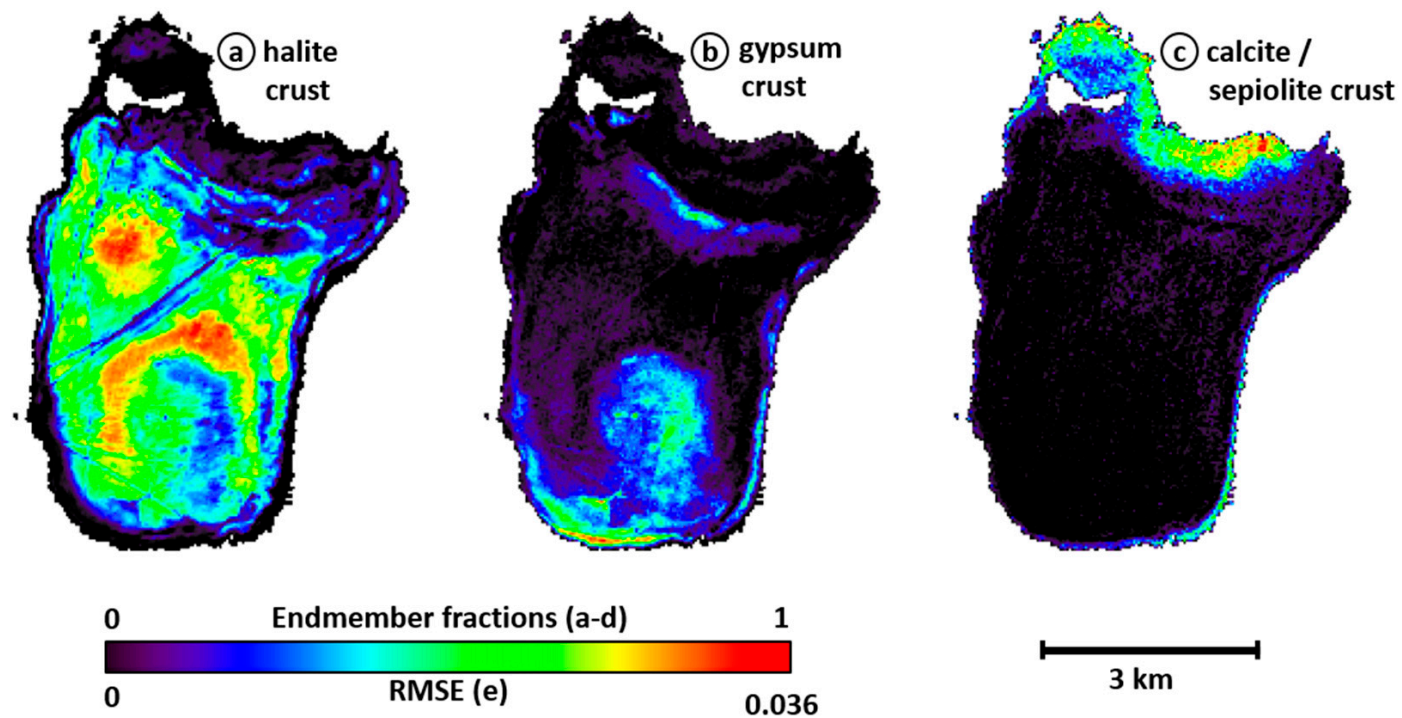

$3 \mathbf{~ k m}$
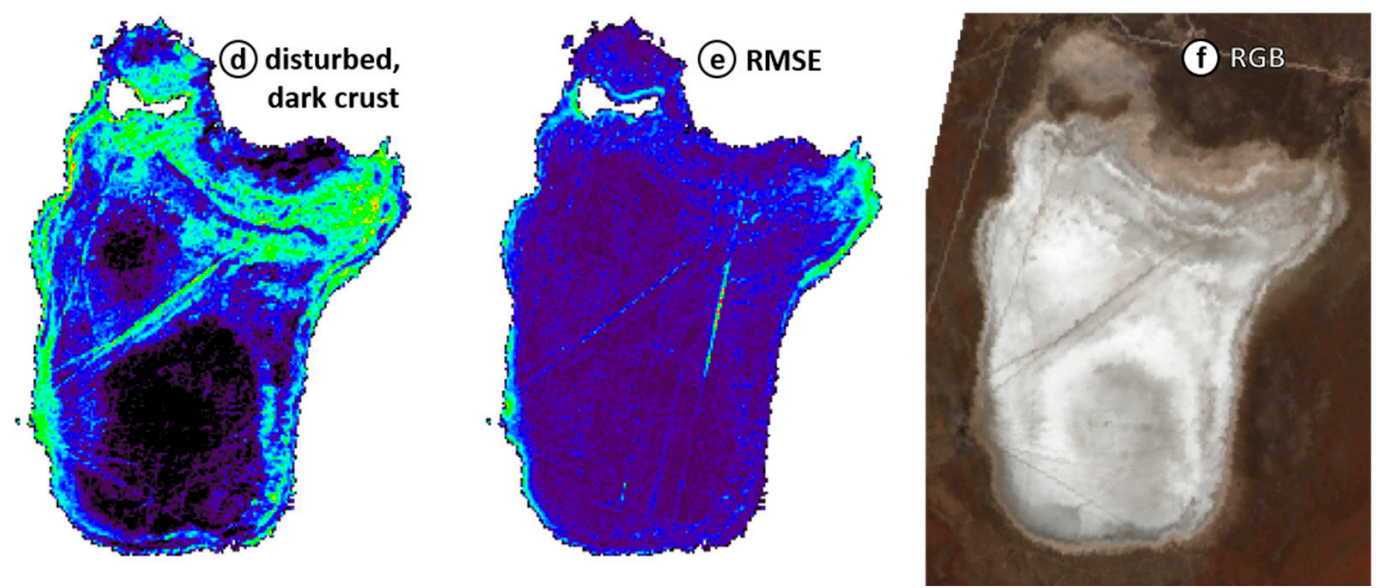

Figure 5. Hyperion mineralogical analysis: Endmember abundances and RMSE of linear spectral unmixing analysis: (a) halite; (b) gypsum; (c) calcite/sepiolite; (d) disturbed, dark crust; (e) RMSE; and (f) RGB (R: $641 \mathrm{~nm}, \mathrm{G}: 549 \mathrm{~nm}, \mathrm{~B}: 457 \mathrm{~nm}$ ) true color Hyperion image.

\subsection{Remote Sensing Change Detection Analyses}

Figure 6 shows the result of the IR-MAD analysis. It represents the mean of the 115 IR-MAD $\chi^{2}$ images derived from the Landsat scene dry surface conditions of the period 1984-2015. The change magnitude map reveals that the salt pan is a highly dynamic and also heterogeneous landform. Compared to the changes of pan surface, the magnitude of spectral change in the surrounding Kalahari savannah is insignificant, which include the seasonal dynamic of the vegetation. Other change signals outside of the pan are of anthropogenic origin associated with housing activity in the southwest of the pan (see few pixels south of the pan in Figure 6) and a gravel road in the north of the pan. Within the pan, a gradient of change is determined from a very stable pan border to a highly dynamic central pan. The small northern sub-pan, where P68 and P69 are located (Figure 1), is very stable compared to the main pan body. The changes in the central part of the pan are very heterogeneous. Two regions of highest change (red colour in Figure 6) are identified located in the north of a circular area in the 
central southern part of the pan and a corridor in the northern part of the pan. In relation to the highest change in the pan center, several distinctive regions of lower change can be identified. For example straight lines crossing the pan as well as the mentioned circular shape have lower change magnitude compared to their surroundings. The largest of these lines crosses the pan center and is associated with a pathway that connects settlements in the west and northeast of the pan.

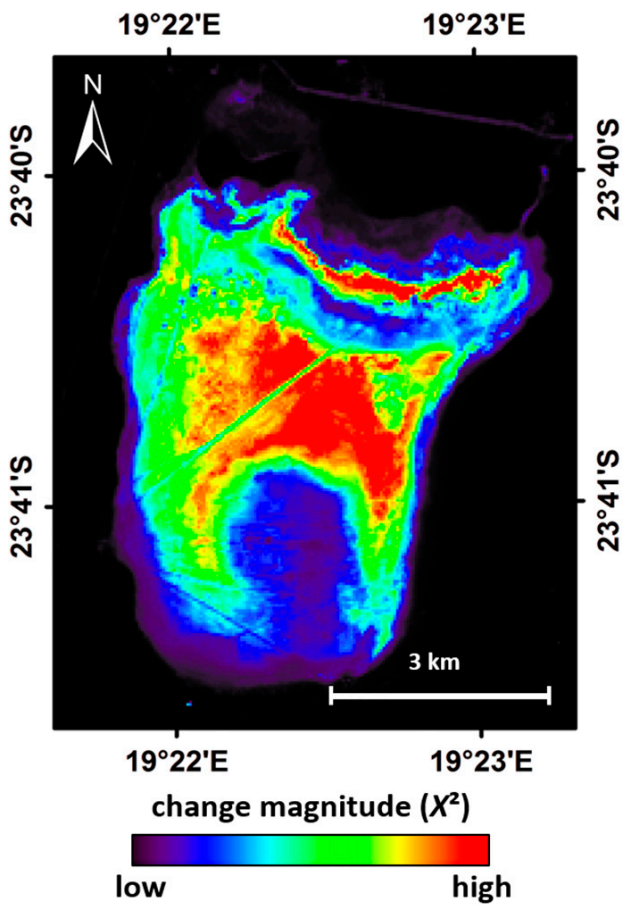

Figure 6. Landsat multitemporal analysis: Change magnitude map that represents the mean of 115 IR-MAD $\chi^{2}$ images (1984-2015).

\section{Discussion}

\subsection{Pan Surface Characterisation}

The combined remote sensing results over the Omongwa pan based on Landsat change detection analyses, Hyperion mineralogical identification and mapping and the LIDAR elevation model are summarized in Figure 7. Hyperion mineralogical identification agrees with the findings of previous studies [27] based on conventional point-based field sampling. The main mineralogical constituents of the top layer of the pan deposits described in [27], namely: quartz, halite, gypsum, calcite and sepiolite could be identified in our XRD analyses and furthermore Hyperion satellite imagery was able to provide spatial distribution of the major crust types and abundance maps over the whole pan. However, no indication of muscovite or smectite (described to occur in traces in [27]) were found in our analyzed field samples nor were these minerals recognized in the spectral properties of in-situ or laboratory measurements. This discrepancy may be the result of different sampling locations or depth. In this study the top $<2 \mathrm{~cm}$ of the pan deposits were sampled, unfortunately [27] does not provide spatial differentiation of the mineralogy or state the specific sampling depth, which prevents further evaluation. Another possible explanation is a change in exposed surface mineralogy. The mineralogical data published by [27] were sampled in 1991 and 1992. During this $>20$ years time frame the surface alteration, e.g., by redistribution of surface particles due to surface flooding [15] and or wind erosion [9] are possible scenarios. The formation of fresh halite crust after significant rainfall and flooding events may superimpose underlying less soluble (e.g., clastic) minerals [110] and hide these (minor) components from surface observations, especially in the central halite dominated, 
dynamic part of the salt pan. The detection of minor crust components may be also limited by the low signal-to-noise ratio of the Hyperion data [16,23]. However, the spectral properties of the most abundant crust components are represented in the selected endmember spectra of the generalized major crust types. Figure 7 shows that the different areas of surface change appear to be well correlated to the crust mineralogical mapping as well as pan morphology. Areas associated with high change magnitudes are located in the central part of the pan, which is dominated by halite mineralogy and lower topographical areas. Gypsum crust is the second most abundant crust type of the Omongwa pan (Figure 7b). Unlike the halite crust, the gypsum area mapped with Hyperion is associated with more stable or intermediately dynamic surface regions in the multitemporal analysis (Figure 7a) and slightly higher topography (Figure 7c). Although the difference in pan height of 10-15 cm between halite dominated and gypsum mixed crust is rather small, it seems to be enough to affect the surface mineralogy.

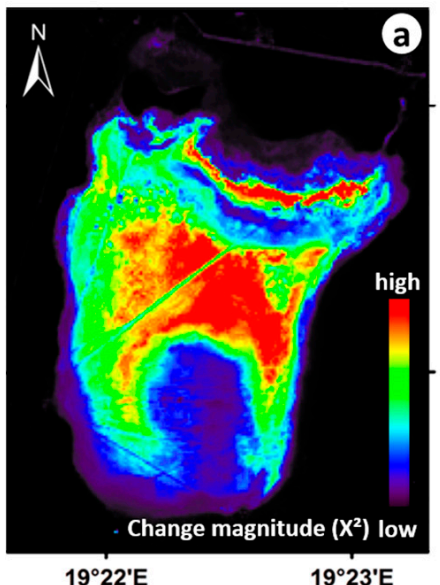

$19^{\circ} 22$ 'E

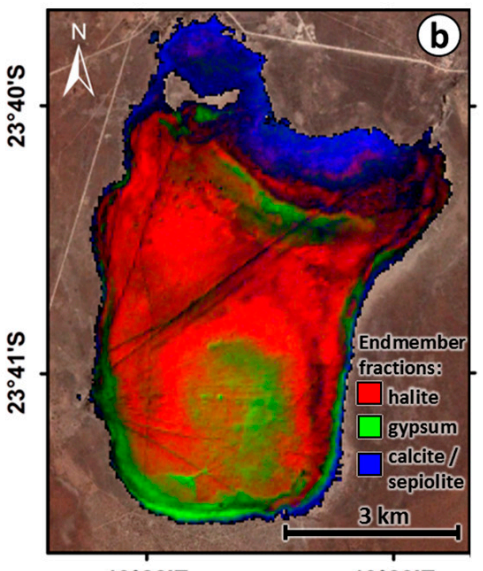

$19^{\circ} 22 ' E$

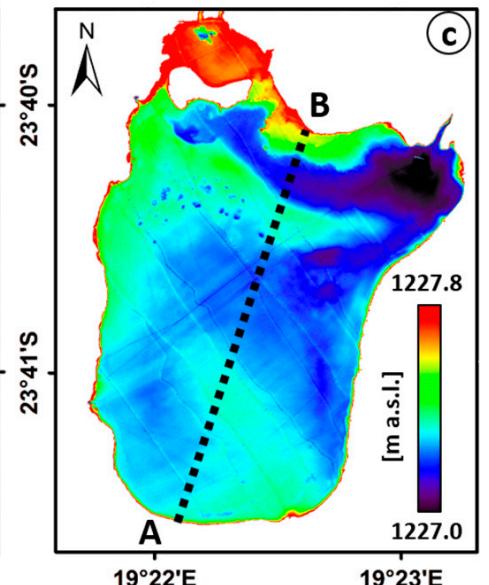

$19^{\circ} 22^{\prime} \mathrm{E}$

Figure 7. Omongwa pan remote sensing analysis: (a) Landsat change magnitude map (1984-2015); (b) Hyperion mineralogical map (09/2014); and (c) DEM derived from LiDAR survey. A-B locates the spatial transect shown in Figure 9.

Figure 8 presents the relationship between endmember abundance and digital elevation model resampled to Hyperion spatial scale. For clarity not all Hyperion pixels are shown, rather a Random Stratified Sampling (RSS) pixel selection is represented. RSS is used to respect the pixel distribution over all elevations and put emphasis on the extreme elevations that represent $\sim 33 \%$ of the total pan area. The figure shows that pan depressions (areas lower than $1227.25 \mathrm{~m}, \sim 18 \%$ of the total pan area) are dominated by halite crust (box A in Figure 8) and higher topographical positions (areas higher than $1227.4 \mathrm{~m}, \sim 15 \%$ of the total pan area) are dominated by gypsum crust (box B in Figure 8 ), whereas the majority of pixels with more mixed crust abundances are present at the medium elevations. 


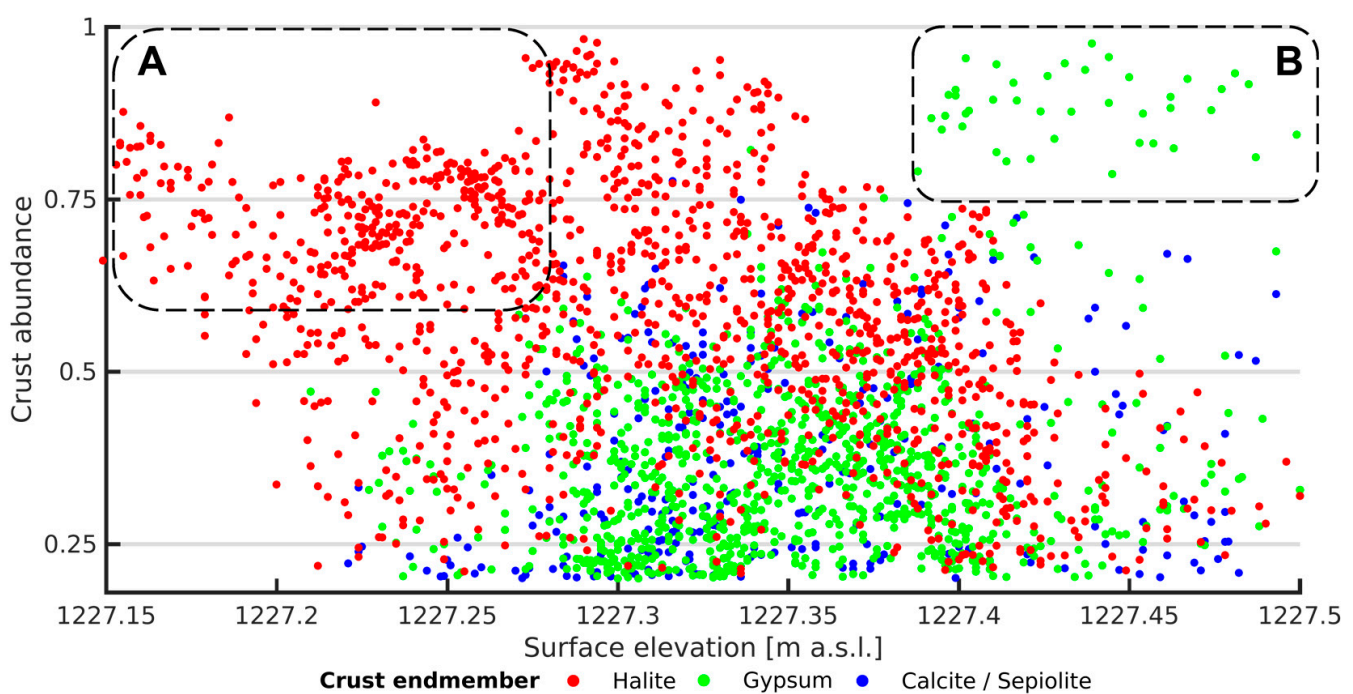

Figure 8. Relationship of pan surface elevation and crust endmember abundance. Box A marks high halite content at low elevations and box $\mathbf{B}$ marks high gypsum content at high elevations.

\subsection{Interpretation of Pan Surface Processes and Depositional Environment}

The interpretation of the observed differences in pan surface dynamic, mineralogy and morphology based on the remote sensing findings confirms that Omongwa pan follows the conceptual model of the depositional cycle of salt pan environments given by Lowenstein and Hardie [15], and that this sediment dynamic can be spatially mapped with advanced remote sensing analyses such as in this paper. The conceptual model describes the reaction of pan deposits to a precipitation event. The stages of these pan cycle are: (1) desiccation stage (dry saline pan); (2) flooding stage (brackish pan); (3) evaporative concentration stage (saline pan); and the return to (1) desiccation stage (dry saline pan). Starting from the dry pan state (stage 1) ephemeral inundation events occur that cover parts or rarely even total surface area of the pan. Evaporite minerals will be dissolved by undersaturated meteoric water and redistributed over the pan mainly following the topography (stage 2). Halite is one of the less stable (more soluble) evaporite minerals and will be quickly leached into the brine and removed from the uppermost surface layer [111], whereas gypsum and calcite are more stable (less soluble) [112] and therefore are more likely to remain in the surface crust in higher abundancies, which is what we observe in the Hyperion mapping where high gypsum and calcite areas are more concentrated on the borders of the pan, which are also the most stable areas as identified in the Landsat time-series change analyses. After some time of continued evaporation the increasingly concentrated brine will accumulate in the local depressions (stage 3). In these saline brine pools the dissolved solutes will (re-)precipitate in reversed order of solubility. Gypsum crystals will form first in the brine pool and halite will be the last evaporite mineral that forms on top of the other deposits [111] resulting in a most pure efflorescent salt crust surface layer. In summary, the increasing concentration of brine leads to a horizontal zonation of evaporite minerals ordered by solubility. Such a "bulls eye" effect of lateral zonation of evaporite minerals from carbonates at the edge, through sulfates to chlorides in the topographically lower, central part are also observed in other salt pans $[2,113]$. Influences that complicate this idealized model of evaporite mineral deposition and zonation that lead to a more complex distribution are (1) high groundwater levels during flooding events that affect the surface brine chemical composition and its saturation stage in respective to the ions of evaporite minerals [112]; (2) strong winds can move the standing waterbody on the very low-angle salt pan [1] during the brine concentration stage (stage 3) ignoring the minimal elevation differences. Subsurface brines of the Omongwa pan that were sampled in 1991 at the end of the raining season by [27] were Na-K-Cl-SO 4 dominated with a total dissolved solids concentration of about $260 \mathrm{~g} / \mathrm{L}$, 
which basically reflect the elemental composition of the mapped surface evaporite minerals. When the diluted meteoric water mix with these groundwater brines it lowers the potential for dissolving the surface crust evaporite minerals.

The highest change magnitude in the halite crust region detected with the multitemporal remote sensing analyses correlates very well with the regular build-up of bright efflorescent halite crust described by the model of the pan depositional cycle. During each flooding-and-desiccation cycle, the surface albedo will significantly lower after a rainfall event due to (partly) dissolved halite curst and potentially from some remaining moist sediments at the surface and will increase again, when the surface has dried and the halite crust is reformed. This means, episodic flooding events are likely to be the main driver for the observed Landsat change in surface reflectance linked to crust dynamic. The reformation of a surface salt crust during the desiccation stage is typical for the wet playas type with shallow $(<5 \mathrm{~m})$, fluctuating ground water table described by [9]. In these types of salt pans capillary action in the sediments allows for continuous evaporation from shallow ground water that results in the formation of evaporite minerals in the capillary fringe zone as well as directly on the surface [9]. This categorization is supported by the observed evaporite filled cracks and fissures in the first $50 \mathrm{~cm}$ of sediments reported by [27] throughout vertical profiles of the Omongwa pan. These efflorescent salt crusts that form directly from evaporation at the surface are commonly very soft and fluffy and have a high potential for dust emission even under moderate winds [10]. The soft consistency of the upper $\sim 10 \mathrm{~cm}$ of halite rich sediments has been also observed for the Omongwa pan [27]. Over time theses soft surfaces have the potential to become crusted surfaces sufficiently thick to shut down all dust emission, through receding groundwater levels during the dry season or extended periods without rainfall [9]. However, the high change magnitudes in the Landsat multitemporal analysis indicate that the halite crust is periodically dissolved and reprecipitated, thus do not support that in Omongwa long-remaining hard layered halite crusts are regularly formed.

Following the idea of [114], proportion maps of the mineralogical crust type can be used to classify the depositional environment of a salt pan. In this study the approach is adapted to the different geomorphological setting of the Omongwa pan (bordering calcite bedrock instead of clastic alluvial facies) and complemented by the topographic information and the change detection result. Figure 9 shows an exemplary South-North profile of Hyperion mineralogical mapping compared with Landsat $\sim 30$ years dynamic mapping and LiDAR topography that crosses the different depositional zones of the Omongwa pan (location of the profile is giving in Figure 7c). Six zones with three different levels of activity are recognized. The most southern surface is dominated by high proportions of gypsum crust (40\%-90\%) with some calcite/sepiolite crust (up to $30 \%$ ) and lower gypsum content at the very beginning. This very stable gypsiferous surface represents the southern pan margin with increasing topography in direction of the lunette dune. As the profile moves north an increase in halite crust abundance (up to $70 \%$ ) and a decrease in gypsum abundance (around 30\%) is observed. This mixture dominated saline mud flat [114] is more active compared to the pan margin, but still more stable than the lower central depression of the salt pan. Further north the gypsum fraction in the surface sediment quickly declines and halite increases further. This very dynamic region dominated by high halite proportions (between 50\% and 95\%) can be interpreted as the central area of saline pan sediments [13,15]. This is the aforementioned region where build-up of bright efflorescent halite crust alternates with more moist phases and lower surface albedo in each recurring inundation cycle. To the north the saline pan zone is bordered by a slight increase in topography $(\sim 10 \mathrm{~cm})$ that results in conditions similar to the southern mud flat with lower surface dynamic and mineralogical mixture of halite, gypsum, but also northward increase of calcite/sepiolite. North of this elevated ridge position the halite fraction increases again and comparable condition to the central saline pan are met. This linear shaped depression in the north of the pan originates from a short, poorly developed channel that feeds into the depression at the northeastern pan margin and is active during significant rainfall events (Figure 7c). The channel was observed to hold water for several days after a rainfall in October 2014 and June 2015. The transect ends at the stable pan margin dominated by the calcite/sepiolite 
mudstone bedrock that seems to deposit into the adjacent halite dominated depression. Additionally, anthropogenic disturbance lead to modification of the original salt crust especially at the pan border, where the fresh efflorescent halite crust is removed and mineralogically more mixed material emerges from the subsurface that is less cohesive and can more easily contribute to dust emission.

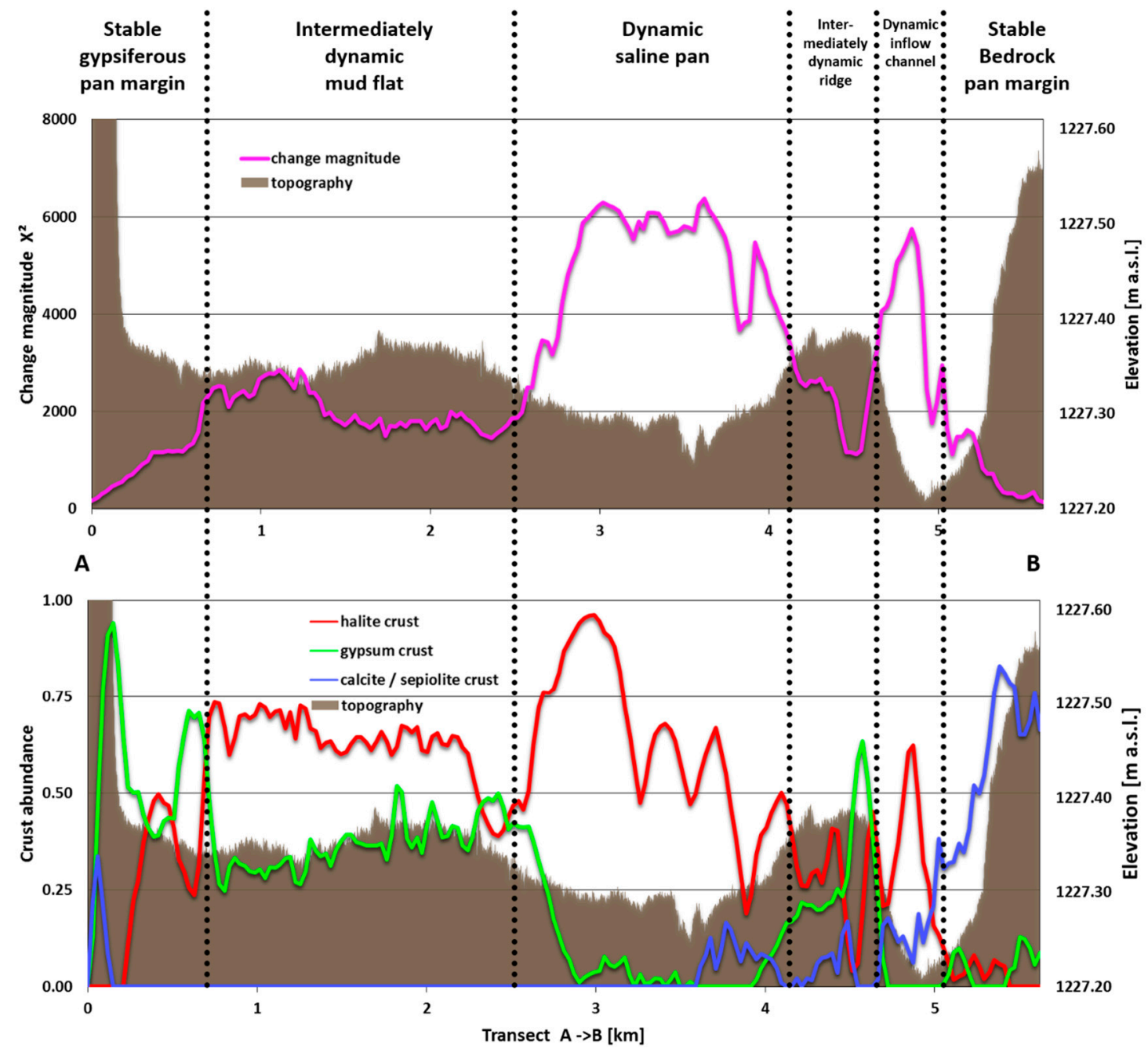

Figure 9. Spatial profile through the Omongwa salt pan (A-B, SW to NE, marked in Figure 7c). Pan topography, vertical exaggeration $\sim 5000 x$ (filled graph) is shown with Landsat change magnitude (top), and Hyperion mineralogical abundances (bottom).

\section{Conclusions}

In this paper, combined multitemporal and hyperspectral remote sensing analyses over the Omongwa salt pan in the Namibian Kalahari region are used to spatially differentiate and map depositional environments within the pan that deepen our knowledge of the local surface processes. Additional field and laboratory measurements and LiDAR topographical survey support the interpretation. The results show that the major salt pan mineralogical crust types (halite, gypsum, sepiolite/calcite, disturbed dark crust) could be spatially and spectrally well differentiated by Spectral Mixture Analysis on the basis of to EO-1 Hyperion imagery. The spatial distribution patterns of the mineralogical crust types correlate well with the Landsat $\sim 30$ years change map of the pan surface derived with IR-MAD analysis. A Highly dynamic pan center is identified that is dominated by halite crust, whereas at the more stable pan margins and the southern parts of the pan gypsum and calcite/sepiolite crusts are more common. The surface change map relates well to different 
susceptibility to pan inundation events according to the solubility of the evaporite minerals as described in conceptual models of the depositional cycle within salt pan environments. Whereas halite is more easily dissolved even by small precipitation events, gypsum and calcite are more likely to remain in the surface layer. Our analyses provide for the first time a deep understanding of the spatial distribution of the fresh efflorescent salt crust formation and the influence of pan morphology. The change detection map also does not support the presence of long-lasting stable halite crust but rather confirm and detail the dynamic aspect of the distribution of halite crust, due to climatic and anthropogenic influences. The study also shows that the detailed morphological information provided by the LiDAR DSM could complement the analysis of surface mineralogy and dynamic and could contribute to the classification of salt pan's depositional environment related to topographical position. While dynamic halite crust dominates most of the surface area and especially the lower regions, more stable gypsum and calcite/sepiolite crust appear to concentrate in higher areas.

The results demonstrate the potential of current advanced remote sensing optical methodologies for the improvement of our knowledge on pan surface processes. To further deepen the understanding of the pan environment and its responses to climatic events, future work should focus on high temporal monitoring of hydrological parameters such as groundwater flow, precipitation and flooding events that could lead to insights into major driving factors for the observed surface change and mineralogical patterns both in the dry and in the wet seasons. Further improvement on the classification of the pan surface and its properties lies in the combination of the presented approach with RADAR based multitemporal assessments of the surface roughness. Nevertheless, in this paper, with newly available Earth observation techniques the full complexity of a saline pan dynamic could be spatially described, combining mineralogical and topographical mapping with $\sim 30$ years change detection analyses. The Omongwa pan is presented as an exemplarily object of study to test the potential of new remote sensing techniques. The approach used in this study is not pan-specific and could be well transferred and applied for the study of arid landscapes and salt pan characterization in the region and in other arid regions of the world. The proposed framework of methods is also relevant regarding upcoming remote sensing technology. For example, regarding the planned and upcoming Earth Observation missions equipped with high quality imaging spectrometers, such as the German Environmental Mapping and Analysis Program (EnMAP) mission [115], hyperspectral analyses, such as the proposed mineralogical pan surface characterization, will become available even for extensive sites on a more regular temporal basis. A better, wider characterization of pan mineralogy would also support further studies on pan susceptibility for wind erosion and contribute to assessment of potential dust emissions.

Acknowledgments: This work was funded by the German Federal Ministry of Education and Research (BMBF) as part of the joint project "GeoArchives-Signals of Climate and Landscape Change preserved in Southern African GeoArchives" (No. 03G0838A) within the "SPACES Program-Science Partnerships for the Assessment of Complex Earth System Processes" research initiative. Project partners from GFZ, TUM and SaM are gratefully acknowledged for intensive joint field works and science discussions. Additionally, we wish to thank Christian Mielke and Luis Guanter for support and helpful comments with the data preprocessing, Daniel Berger for help with the field work, and Anja Maria Schleicher for support with the XRD analysis, as well as Hartmut Liep and Marina Ospald for the sample preparation. The authors also thank the USGS and NASA for providing Landsat and Hyperion data, especially Stuart Frye and the EO-1 Science Team for acquiring the Hyperion datasets that were used in this study.

Author Contributions: Robert Milewski developed the overall idea and approach supported by Sabine Chabrillat. Robert Milewski conducted the image processing and analysis. Robert Behling contributed to the methodological programming and adaptation of the IR-MAD as well as fieldwork. Robert Milewski and Sabine Chabrillat prepared the manuscript.

Conflicts of Interest: The authors declare no conflict of interest.

\section{References}

1. Millington, A.C.; Drake, N.A.; Townshend, J.R.G.; Quarmby, N.A.; Settle, J.J.; Reading, A.J. Monitoring salt playa dynamics using Thematic Mapper data. IEEE Trans. Geosci. Remote Sens. 1989, 27, 754-761. [CrossRef] 
2. Shaw, P.A.; Bryant, R.G. Pans, Playas and Salt Lakes. In Arid Zone Geomorphology; Thomas, D.S.G., Ed.; John Wiley \& Sons, Ltd.: London, UK, 2011; pp. 373-401.

3. Neal, J.T. Playa surface features as indicators of environment. In Playas and Dried Lakes; Neal, J.T., Ed.; Dowden, Hutchinson \& Ross: Stroudsburg, PA, USA, 1975; pp. 363-380.

4. Rosen, M.R. Paleoclimate and Basin Evolution of Playa Systems; Geological Society of America: Boulder, CO, USA, 1994.

5. Washington, R.; Todd, M.; Middleton, N.J.; Goudie, A.S. Dust-Storm Source Areas Determined by the Total Ozone Monitoring Spectrometer and Surface Observations. Ann. Assoc. Am. Geogr. 2003, 93, 297-313. [CrossRef]

6. Prospero, J.M.; Ginoux, P.; Torres, O.; Nicholson, S.E.; Gill, T.E. Environmental Characterization of Global Sources of Atmospheric Soil Dust Identified with the Nimbus 7 Total Ozone Mapping Spectrometer (Toms) Absorbing Aerosol Product. Rev. Geophys. 2002, 40, 1002. [CrossRef]

7. Vickery, K.J.; Eckardt, F.D.; Bryant, R.G. A sub-basin scale dust plume source frequency inventory for southern Africa, 2005-2008. Geophys. Res. Lett. 2013, 40, 5274-5279. [CrossRef]

8. Nield, J.M.; Bryant, R.G.; Wiggs, G.F.S.; King, J.; Thomas, D.S.G.; Eckardt, F.D.; Washington, R. The dynamism of salt crust patterns on playas. Geology 2015, 43, 31-34. [CrossRef]

9. Reynolds, R.L.; Yount, J.C.; Reheis, M.; Goldstein, H.; Chavez, P.; Fulton, R.; Whitney, J.; Fuller, C.; Forester, R.M. Dust emission from wet and dry playas in the Mojave Desert, USA. Earth Surf. Process. Landf. 2007, 32, 1811-1827. [CrossRef]

10. Buck, B.J.; King, J.; Etyemezian, V. Effects of Salt Mineralogy on Dust Emissions, Salton Sea, California. Soil Sci. Soc. Am. J. 2011, 75, 1971-1985. [CrossRef]

11. Katra, I.; Lancaster, N. Surface-sediment dynamics in a dust source from spaceborne multispectral thermal infrared data. Remote Sens. Environ. 2008, 112, 3212-3221. [CrossRef]

12. Thomas, A.D.; Dougill, A.J.; Elliott, D.R.; Mairs, H. Seasonal differences in soil $\mathrm{CO}_{2}$ efflux and carbon storage in Ntwetwe Pan, Makgadikgadi Basin, Botswana. Geoderma 2014, 219-220, 72-81. [CrossRef]

13. Bryant, R.G. Validated linear mixture modelling of Landsat TM data for mapping evaporite minerals on a playa surface: methods and applications. Int. J. Remote Sens. 1996, 17, 315-330. [CrossRef]

14. Drake, N.A. Reflectance spectra of evaporite minerals (400-2500 nm): Applications for remote sensing. Int. J. Remote Sens. 1995, 16, 2555-2571. [CrossRef]

15. Lowenstein, T.K.; Hardie, L.A. Criteria for the recognition of salt-pan evaporites. Sedimentology 1985, 32, 627-644. [CrossRef]

16. Alanazi, H.A.; Ghrefat, H.A. Spectral Analysis of Multispectral Landsat 7 ETM + and ASTER Data for Mapping Land Cover at Qurayah Sabkha, Northern Saudi Arabia. J. Indian Soc. Remote Sens. 2013, 41, 833-844. [CrossRef]

17. Li, J.; Menenti, M.; Mousivand, A.; Luthi, S.M. Non-Vegetated Playa Morphodynamics Using Multi-Temporal Landsat Imagery in a Semi-Arid Endorheic Basin: Salar de Uyuni, Bolivia. Remote Sens. 2014, 6, 10131-10151. [CrossRef]

18. Chapman, J.E.; Rothery, D.A.; Francis, P.W.; Pontual, A. Remote sensing of evaporite mineral zonation in salt flats (salars). Int. J. Remote Sens. 1989, 10, 245-255. [CrossRef]

19. White, K.; Eckardt, F. Geochemical mapping of carbonate sediments in the Makgadikgadi basin, Botswana using moderate resolution remote sensing data. Earth Surf. Process. Landf. 2006, 31, 665-681. [CrossRef]

20. Hubbard, B.E.; Crowley, J.K. Mineral mapping on the Chilean-Bolivian Altiplano using co-orbital ALI, ASTER and Hyperion imagery: Data dimensionality issues and solutions. Remote Sens. Environ. 2005, 99, 173-186. [CrossRef]

21. Kodikara, G.R.L.; Woldai, T.; van Ruitenbeek, F.J.A.; Kuria, Z.; van der Meer, F.; Shepherd, K.D.; van Hummel, G.J. Hyperspectral remote sensing of evaporate minerals and associated sediments in Lake Magadi area, Kenya. Int. J. Appl. Earth Obs. Geoinf. 2012, 14, 22-32. [CrossRef]

22. Green, R.O.; Pavri, B.E.; Chrien, T.G. On-orbit radiometric and spectral calibration characteristics of EO-1 Hyperion derived with an underflight of AVIRIS and in situ measurements at Salar de Arizaro, Argentina. IEEE Trans. Geosci. Remote Sens. 2003, 41, 1194-1203. [CrossRef]

23. Thome, K.J.; Biggar, S.F.; Wisniewski, W. Cross comparison of EO-1 sensors and other Earth resources sensors to Landsat-7 ETM+ using Railroad Valley Playa. IEEE Trans. Geosci. Remote Sens. 2003, 41, 1180-1188. [CrossRef] 
24. Dutkiewicz, A.; Lewis, M.; Ostendorf, B. The Suitability of Airborne Hyperspectral Imagery for Mapping Surface Indicators of Salinity in Dryland Farming Area. In Remote Sensing of Soil Salinization: Impact on Land Management; CRC Press: Boca Raton, FL, USA, 2008; pp. 93-112.

25. Kruse, F.A.; Boardman, J.W.; Huntington, J.F. Comparison of airborne hyperspectral data and EO-1 Hyperion for mineral mapping. IEEE Trans. Geosci. Remote Sens. 2003, 41, 1388-1400. [CrossRef]

26. Crowley, J.K.; Hubbard, B.E.; Mars, J.C. Analysis of potential debris flow source areas on Mount Shasta, California, by using airborne and satellite remote sensing data. Remote Sens. Environ. 2003, 87, 345-358. [CrossRef]

27. Mees, F. Distribution patterns of gypsum and kalistrontite in a dry lake basin of the southwestern Kalahari (Omongwa pan, Namibia). Earth Surf. Process. Landf. 1999, 24, 731-744. [CrossRef]

28. Mees, F.; Van Ranst, E. Micromorphology of sepiolite occurrences in recent lacustrine deposits affected by soil development. Soil Res. 2011, 49, 547-557. [CrossRef]

29. Kautz, K.; Parada, H. Sepiolote formation in a pan of the Kalahari, South West Africa. J. Mineral. Geochem. 1976, 12, 545-559.

30. Lancaster, N. Pans in the southwestern Kalahari. A preliminary report. Palaeoecol. Afr. 1986, 17, 59-68.

31. Köppen, W.P.; Geiger, R. Handbuch der Klimatologie in fünf bänden; Verlag von Gebrüder Borntraeger: Berlin, Germany, 1930.

32. Atlas of Namibia Project Atlas of Namibia Project (2002) Directorate of Environmental Affairs, Minitry of Environment and Tourism. Available online: http://www.uni-koeln.de/sfb389/e/e1/download/atlas_ namibia/e1_download_climate_e.htm (accessed on 24 November 2015).

33. Thomas, D.; Shaw, P.A. The Kalahari Environment; Cambridge University Press: Cambridge, UK, 1991.

34. Van Veleen, M.; Baker, T. Feasibility Study of the Potential for Sustainable Water Resources Development in the Molopo-Nossob Watercourse, 2009. Available online: http://iwlearn.net/resources/documents/3516 (accessed on 16 February 2017).

35. Miller, R.M. The Geology of Namibia: Upper Palaeozoic to Cenozoic; Ministry of Mines and Energy, Geological Survey of Namibia: Windhoek, Namibia, 2008.

36. Mees, F. The nature of calcareous deposits along pan margins in eastern central Namibia. Earth Surf. Process. Landf. 2002, 27, 719-735. [CrossRef]

37. SACS (South African Committee for Stratigraphy). Stratigraphy of South Africa. Part 1: Lithostratigraphy of the Republic of South Africa, South West Africa/Namibia and the Republics of Bophuthatswana, Transkei and Venda; Geological Survey of South Africa: Johannesburg, South Africa, 1980.

38. JICA Study Team. The Study on the Groundwater Potential Evaluation and Management Plan in the Southeast Kalahari(Stampriet) Artesian Basin in the Republic of Namibia: Final Report: Data Book; Pacific Consultants International: Tokyo, Japan, 2002.

39. FAO. World Reference Base for Soil Resources 2006. A Framework for International Classification, Correlation and Communication; Word Soil Resources Report 103; IUSS-ISRIC-FAO: Rome, Italy, 2006.

40. Stone, A.E.C.; Edmunds, W.M. Sand, salt and water in the Stampriet Basin, Namibia: Calculating unsaturated zone (Kalahari dunefield) recharge using the chloride mass balance approach. Water SA 2012, 38, 367-378. [CrossRef]

41. Local Office of the Namibian Ministries of Agriculture, Basic Education and Health. Personal communication, 2015.

42. ASD Inc. Field Spec_User Manual 2010. Available online: http://support.asdi.com/Document/Viewer. aspx?id=108 (accessed on 16 February 2017).

43. Soil Quality—Determination of Particle Size Distribution in Mineral Soil Material—Method by Sieving and Sedimentation (ISO 11277:1998 + ISO 11277:1998 Corrigendum 1:2002) 2002. Available online: http: / /www.iso.org/iso/catalogue_detail.htm?csnumber=54151 (accessed on 16 February 2017).

44. Soil Quality-Determination of the Specific Electrical Conductivity (ISO 11265:1994 + ISO 11265:1994/Corr.1:1996) 1997. Available online: http://www.iso.org/iso/catalogue_detail.htm? csnumber=19243 (accessed on 16 February 2017).

45. EarthExplorer. Available online: http:/ / earthexplorer.usgs.gov/ (accessed on 16 February 2017).

46. Chander, G.; Markham, B.L.; Helder, D.L. Summary of current radiometric calibration coefficients for Landsat MSS, TM, ETM+, and EO-1 ALI sensors. Remote Sens. Environ. 2009, 113, 893-903. [CrossRef] 
47. Masek, J.G.; Vermote, E.F.; Saleous, N.E.; Wolfe, R.; Hall, F.G.; Huemmrich, K.F.; Gao, F.; Kutler, J.; Lim, T.-K. LEDAPS Calibration, Reflectance, Atmospheric Correction Preprocessing Code, version 2, 2013. Available online: https:/ / daac.ornl.gov/cgi-bin/dsviewer.pl?ds_id=1146 (accessed on 16 February 2017).

48. Masek, J.G.; Vermote, E.F.; Saleous, N.E.; Wolfe, R.; Hall, F.G.; Huemmrich, K.F.; Gao, F.; Kutler, J.; Lim, T.-K. A Landsat surface reflectance dataset for North America, 1990. IEEE Geosci. Remote Sens. Lett. 2006, 3, 68-72. [CrossRef]

49. United States Geological Survey (USGS). Product Guide. Provisional Landsat 8 Surface Reflectance Product; United States Geological Survey: Boulder, CO, USA, 2015; p. 27.

50. Kaufman, Y.J.; Wald, A.E.; Remer, L.A.; Gao, B.-C.; Li, R.-R.; Flynn, L. The MODIS 2.1- $\mu$ m channel-correlation with visible reflectance for use in remote sensing of aerosol. IEEE Trans. Geosci. Remote Sens. 1997, 35, 1286-1298. [CrossRef]

51. Maiersperger, T.K.; Scaramuzza, P.L.; Leigh, L.; Shrestha, S.; Gallo, K.P.; Jenkerson, C.B.; Dwyer, J.L. Characterizing LEDAPS surface reflectance products by comparisons with AERONET, field spectrometer, and MODIS data. Remote Sens. Environ. 2013, 136, 1-13. [CrossRef]

52. Vermote, E.; Justice, C.; Claverie, M.; Franch, B. Preliminary analysis of the performance of the Landsat 8/OLI land surface reflectance product. Remote Sens. Environ. 2016, 185, 46-56. [CrossRef]

53. $\mathrm{Xu}, \mathrm{H}$. Modification of normalised difference water index (NDWI) to enhance open water features in remotely sensed imagery. Int. J. Remote Sens. 2006, 27, 3025-3033. [CrossRef]

54. Li, W.; Du, Z.; Ling, F.; Zhou, D.; Wang, H.; Gui, Y.; Sun, B.; Zhang, X. A Comparison of Land Surface Water Mapping Using the Normalized Difference Water Index from TM, ETM+ and ALI. Remote Sens. 2013, 5, 5530-5549. [CrossRef]

55. Verbesselt, J.; Hyndman, R.; Newnham, G.; Culvenor, D. Detecting trend and seasonal changes in satellite image time series. Remote Sens. Environ. 2010, 114, 106-115. [CrossRef]

56. Pesaran, M.H.; Timmermann, A. Market timing and return prediction under model instability. J. Empir. Financ. 2002, 9, 495-510. [CrossRef]

57. DeVries, B.; Verbesselt, J.; Kooistra, L.; Herold, M. Robust monitoring of small-scale forest disturbances in a tropical montane forest using Landsat time series. Remote Sens. Environ. 2015, 161, 107-121. [CrossRef]

58. Verbesselt, J.; Zeileis, A.; Herold, M. Near real-time disturbance detection using satellite image time series. Remote Sens. Environ. 2012, 123, 98-108. [CrossRef]

59. Nielsen, A.A. The Regularized Iteratively Reweighted MAD Method for Change Detection in Multi- and Hyperspectral Data. IEEE Trans. Image Process. 2007, 16, 463-478. [CrossRef] [PubMed]

60. Liao, M.; Zhu, P.; Gong, J. Multivariate Change Detection Based on Canonical Transformation. J. Remote Sens. 2000, 4, 197-201.

61. Pathak, S. New Change Detection Techniques to monitor land cover dynamics in mine environment. ISPRS Int. Arch. Photogramm. Remote Sens. Spat. Inf. Sci. 2014, XL-8, 875-879. [CrossRef]

62. Mezned, N.; Dkhala, B.; Abdeljaouad, S. Multi temporal and multi spectral images based change detection of mine wastes in Northern Tunisia. In Proceedings of the 2015 IEEE International Geoscience and Remote Sensing Symposium (IGARSS), Milan, Italy, 26-31 July November 2015; pp. 3426-3429.

63. Colditz, R.R.; Llamas, R.M.; Gebhardt, S.; Wehrmann, T.; Equihua, J. Comparison of change detection techniques for the Yucatan peninsula using Landsat image time series. In Proceedings of the 2015 IEEE International Geoscience and Remote Sensing Symposium (IGARSS), Milan, Italy, 26-31 July 2015; pp. 1650-1653.

64. Ma, Y.; Chen, F.; Liu, J.; He, Y.; Duan, J.; Li, X. An Automatic Procedure for Early Disaster Change Mapping Based on Optical Remote Sensing. Remote Sens. 2016, 8, 272. [CrossRef]

65. Hoja, D.; Krauss, T.; Reinartz, P. Detailed damage assessment after the Haiti earthquake. In Earth Observation of Global Changes (EOGC); Springer: Berlin, Germany, 2013; pp. 193-204.

66. Zhang, L.; Liao, M.; Yang, L.; Lin, H. Remote sensing change detection based on canonical correlation analysis and contextual Bayes decision. Photogramm. Eng. Remote Sens. 2007, 73, 311-318. [CrossRef]

67. Nielsen, A.A. Analysis of Regularly and Irregularly Sampled Spatial, Multivariate, and Multi-Temporal Data; Technical University of Denmark: Lyngby, Denmark, 1994.

68. Coppin, P.; Jonckheere, I.; Nackaerts, K.; Muys, B.; Lambin, E. Digital change detection methods in ecosystem monitoring: A review. Int. J. Remote Sens. 2004, 25, 1565-1596. [CrossRef] 
69. Nielsen, A.A.; Conradsen, K.; Simpson, J.J. Multivariate Alteration Detection (MAD) and MAF Postprocessing in Multispectral, Bitemporal Image Data: New Approaches to Change Detection Studies. Remote Sens. Environ. 1998, 64, 1-19. [CrossRef]

70. Ju, J.; Roy, D.P. The availability of cloud-free Landsat ETM+ data over the conterminous United States and globally. Remote Sens. Environ. 2008, 112, 1196-1211. [CrossRef]

71. Aghamohamadnia, M.; Abedini, A. A morphology-stitching method to improve Landsat SLC-off images with stripes. Geod. Geodyn. 2014, 5, 27-33. [CrossRef]

72. Chen, J.; Zhu, X.; Vogelmann, J.E.; Gao, F.; Jin, S. A simple and effective method for filling gaps in Landsat ETM+ SLC-off images. Remote Sens. Environ. 2011, 115, 1053-1064. [CrossRef]

73. Alexandridis, T.K.; Cherif, I.; Kalogeropoulos, C.; Monachou, S.; Eskridge, K.; Silleos, N. Rapid error assessment for quantitative estimations from Landsat 7 gap-filled images. Remote Sens. Lett. 2013, 4, 920-928. [CrossRef]

74. Bédard, F.; Reichert, G.; Dobbins, R.; Trépanier, I. Evaluation of segment-based gap-filled Landsat ETM+ SLC-off satellite data for land cover classification in southern Saskatchewan, Canada. Int. J. Remote Sens. 2008, 29, 2041-2054. [CrossRef]

75. Canty, M.J. Image Analysis, Classification and Change Detection in Remote Sensing: With Algorithms for ENVI/IDL and Python, 3rd ed.; CRC Press: Boca Raton, FL, USA, 2014.

76. Canty, M.J.; Nielsen, A.A. Linear and kernel methods for multivariate change detection. Comput. Geosci. 2012, 38, 107-114. [CrossRef]

77. Nielsen, A.A.; Hecheltjen, A.; Thonfeld, F.; Canty, M.J. Automatic change detection in RapidEye data using the combined MAD and kernel MAF methods. In Proceedings of the IGARSS 2010-2010 IEEE International Geoscience and Remote Sensing Symposium, Honolulu, HI, USA, 25-30 July 2010; pp. 3078-3081.

78. Liang, W.; Hoja, D.; Schmitt, M.; Stilla, U. Change Detection for Reconstruction Monitoring based on Very High Resolution Optical Data, 2011. Available online: http:/ / elib.dlr.de/69997/1/WenjingLiang_jurse2011_ changedetection_word.pdf (accessed on 16 February 2017).

79. Pearlman, J.S.; Barry, P.S.; Segal, C.C.; Shepanski, J.; Beiso, D.; Carman, S.L. Hyperion, a space-based imaging spectrometer. IEEE Trans. Geosci. Remote Sens. 2003, 41, 1160-1173. [CrossRef]

80. Rogass, C.; Guanter, L.; Mielke, C.; Scheffler, D.; Boesche, N.K.; Lubitz, C.; Brell, M.; Spengler, D.; Segl, K. An automated processing chain for the retrieval of georeferenced reflectance data from hyperspectral EO-1 HYPERION acquisitions. In Proceedings of the EARSeL 34th Symposium, Warsaw, Poland, 16-20 June 2014.

81. Guanter, L.; Segl, K.; Sang, B.; Alonso, L.; Kaufmann, H.; Moreno, J. Scene-based spectral calibration assessment of high spectral resolution imaging spectrometers. Opt. Express 2009, 17, 11594. [CrossRef] [PubMed]

82. Guanter, L.; Richter, R.; Kaufmann, H. On the application of the MODTRAN4 atmospheric radiative transfer code to optical remote sensing. Int. J. Remote Sens. 2009, 30, 1407-1424. [CrossRef]

83. Van der Linden, S.; Rabe, A.; Held, M.; Jakimow, B.; Leitão, P.J.; Okujeni, A.; Schwieder, M.; Suess, S.; Hostert, P. The EnMAP-Box-A Toolbox and Application Programming Interface for EnMAP Data Processing. Remote Sens. 2015, 7, 11249-11266. [CrossRef]

84. Harris Geospatial Solutions Linear Spectral Unmixing (Using ENVI). Available online: http://www.exelisvis. com/docs/LinearSpectralUnmixing.html (accessed on 4 February 2016).

85. Mielke, C.; Muedi, T.; Papenfuss, A.; Boesche, N.K.; Rogass, C.; Gauert, C.D.K.; Altenberger, U.; de Wit, M.J. Multi- and hyperspectral spaceborne remote sensing of the Aggeneys base metal sulphide mineral deposit sites in the Lower Orange River region, South Africa. S. Afr. J. Geol. 2016, 119, 63-76. [CrossRef]

86. Mielke, C.; Rogass, C.; Boesche, N.; Segl, K.; Altenberger, U. EnGeoMAP 2.0—Automated Hyperspectral Mineral Identification for the German EnMAP Space Mission. Remote Sens. 2016, 8, 127. [CrossRef]

87. Adams, J.B.; Smith, M.O.; Johnson, P.E. Spectral mixture modeling: A new analysis of rock and soil types at the Viking Lander 1 Site. J. Geophys. Res. Solid Earth 1986, 91, 8098-8112. [CrossRef]

88. Boardman, J.W.; Kruse, F.A. Automated spectral analysis: A geological example using AVIRIS data, northern Grapevine Mountains, Nevada. In Proceedings of the 10th Thematic Conference on Geologic Remote Sensing, Ann Arbor, MI, USA, 9-12 May 1994; pp. 1407-1418.

89. Tompkins, S. Optimization of endmembers for spectral mixture analysis. Remote Sens. Environ. 1997, 59, 472-489. [CrossRef] 
90. Boardman, J.W. Automating Spectral Unmixing of AVIRIS Data Using Convex Geometry Concepts, 1993. Available online: https://ntrs.nasa.gov/search.jsp?R=19950017428 (accessed on 16 February 2017).

91. Shrestha, D.P.; Margate, D.E.; van der Meer, F.; Anh, H.V. Analysis and classification of hyperspectral data for mapping land degradation: An application in southern Spain. Int. J. Appl. Earth Obs. Geoinf. 2005, 7, 85-96. [CrossRef]

92. Garcia-Haro, F.J.; Gilabert, M.A.; Melia, J. Linear spectral mixture modelling to estimate vegetation amount from optical spectral data. Int. J. Remote Sens. 1996, 17, 3373-3400. [CrossRef]

93. Kruse, F.; Lefkoff, A.; Dietz, J. Expert System-Based Mineral Mapping in Northern Death-Valley, California Nevada, Using the Airborne Visible Infrared Imaging Spectrometer (aviris). Remote Sens. Environ. 1993, 44, 309-336. [CrossRef]

94. Chabrillat, S.; Pinet, P.C.; Ceuleneer, G.; Johnson, P.E.; Mustard, J.F. Ronda peridotite massif: Methodology for its geological mapping and lithological discrimination from airborne hyperspectral data. Int. J. Remote Sens. 2000, 21, 2363-2388. [CrossRef]

95. Metternicht, G.I.; Fermont, A. Estimating erosion surface features by linear mixture modeling. Remote Sens. Environ. 1998, 64, 254-265. [CrossRef]

96. Dennison, P.E.; Roberts, D.A. Endmember selection for multiple endmember spectral mixture analysis using endmember average RMSE. Remote Sens. Environ. 2003, 87, 123-135. [CrossRef]

97. Farifteh, J.; van der Meer, F.; van der Meijde, M.; Atzberger, C. Spectral characteristics of salt-affected soils: A laboratory experiment. Geoderma 2008, 145, 196-206. [CrossRef]

98. Green, A.A.; Berman, M.; Switzer, P.; Craig, M.D. A transformation for ordering multispectral data in terms of image quality with implications for noise removal. IEEE Trans. Geosci. Remote Sens. 1988, 26, 65-74. [CrossRef]

99. Boardman, J.W.; Kruse, F.A.; Green, R.O. Mapping Target Signatures via Partial Unmixing of AVIRIS Data, 1995. Available online: https://ntrs.nasa.gov/search.jsp?R=19950027316 (accessed on 16 February 2017).

100. Dimap-Spectral GmbH_Digital Mapping. Available online: http://www.dimap.asia/ (accessed on 16 February 2017).

101. Hunt, G.R.; Salisbury, J.W.; Lenhoff, C.J. Visible and near infrared spectra of minerals and rocks, IV Sulphides and sulphates. Mod. Geol. 1971, 3, 121-132.

102. Clark, R.N.; Swayze, G.A.; Wise, R.; Livo, E.; Hoefen, T.M.; Kokaly, R.F.; Sutley, S.J. USGS Digital Spectral Library splib06a: U.S. Geological Survey, Digital Data Series 231. Available online: http:/ /speclab.cr.usgs. gov /spectral.lib06 (accessed on 16 February 2017).

103. Howari, F.M.; Goodell, P.C.; Miyamoto, S. Spectral properties of salt crusts formed on saline soils. J. Environ. Qual. 2002, 31, 1453-1461. [CrossRef] [PubMed]

104. Khayamim, F.; Wetterlind, J.; Khademi, H.; Robertson, J.; Faz Cano, A.; Stenberg, B. Using visible and near infrared spectroscopy to estimate carbonates and gypsum in soils in arid and subhumid regions of Isfahan, Iran. J. Infrared Spectrosc. 2015, 23, 155. [CrossRef]

105. Ghosh, G.; Kumar, S.; Saha, S.K. Hyperspectral Satellite Data in Mapping Salt-Affected Soils Using Linear Spectral Unmixing Analysis. J. Indian Soc. Remote Sens. 2012, 40, 129-136. [CrossRef]

106. Zhang, X.; Shang, K.; Cen, Y.; Shuai, T.; Sun, Y. Estimating ecological indicators of karst rocky desertification by linear spectral unmixing method. Int. J. Appl. Earth Obs. Geoinf. 2014, 31, 86-94. [CrossRef]

107. Baddock, M.C.; Zobeck, T.M.; Van Pelt, R.S.; Fredrickson, E.L. Dust emissions from undisturbed and disturbed, crusted playa surfaces: Cattle trampling effects. Aeolian Res. 2011, 3, 31-41. [CrossRef]

108. Metternicht, G.; Zinck, J. Remote sensing of soil salinity: potentials and constraints. Remote Sens. Environ. 2003, 85, 1-20. [CrossRef]

109. Nield, J.M.; Wiggs, G.F.S.; King, J.; Bryant, R.G.; Eckardt, F.D.; Thomas, D.S.G.; Washington, R. Climate-surface-pore-water interactions on a salt crusted playa: Implications for crust pattern and surface roughness development measured using terrestrial laser scanning. Earth Surf. Process. Landf. 2016, 41, 738-753. [CrossRef]

110. Chivas, A.R. Chapter 10 Terrestrial Evaporites. In Geochemical Sediments and Landscapes; Nash, D.J., McLaren, S.J., Eds.; RGS-IBG Book Series; Blackwell Pub.: Malden, MA, USA, 2007; pp. 330-364.

111. Warren, J.K. Evaporites: A Geological Compendium; Springer: Berlin, Germany, 2016.

112. Smith, M.; Compton, J.S. Origin and evolution of major salts in the Darling pans, Western Cape, South Africa. Appl. Geochem. 2004, 19, 645-664. [CrossRef] 
113. Jones, B.F. The hydrology and Mineralogy of Deep Springs Lake, Inyo County, California; Professional Paper; U.S. Govt. Print. Off.: Washington, USA, 1965.

114. Bryant, R.G. The Sedimentology and Geochemistry of Non-Marine Evaporites on the Chott el Djerid, Using Both Ground and Remotely Sensed Data; University of Reading: Reading, UK, 1993.

115. Guanter, L.; Kaufmann, H.; Segl, K.; Foerster, S.; Rogass, C.; Chabrillat, S.; Kuester, T.; Hollstein, A.; Rossner, G.; Chlebek, C.; et al. The EnMAP Spaceborne Imaging Spectroscopy Mission for Earth Observation. Remote Sens. 2015, 7, 8830-8857. [CrossRef]

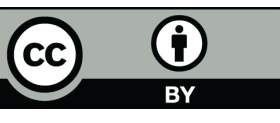

(c) 2017 by the authors; licensee MDPI, Basel, Switzerland. This article is an open access article distributed under the terms and conditions of the Creative Commons Attribution (CC BY) license (http:/ / creativecommons.org/licenses/by/4.0/). 